\title{
REVIEW
}

\section{RabGAPs in skeletal muscle function and exercise}

\author{
Lena Espelage 1,2, Hadi Al-Hasani1,2 and Alexandra Chadt 1,2 \\ 1Institute for Clinical Biochemistry and Pathobiochemistry, German Diabetes Center, Medical Faculty, Leibniz Center for Diabetes Research at Heinrich \\ Heine University Düsseldorf, Düsseldorf, Germany \\ ${ }^{2}$ German Center for Diabetes Research, München-Neuherberg, Germany
}

Correspondence should be addressed to H Al-Hasani: hadi.al-hasani@ddz.de

\begin{abstract}
The two closely related RabGAPs TBC1D1 and TBC1D4 are key signaling factors of skeletal muscle substrate utilization. In mice, deficiency in both RabGAPs leads to reduced skeletal muscle glucose transport in response to insulin and lower GLUT4 abundance. Conversely, Tbc1d1 and Tbc1d4 deficiency results in enhanced lipid use as fuel in skeletal muscle, through yet unknown mechanisms. In humans, variants in TBC1D1 and TBC1D4 are linked to obesity, insulin resistance and type 2 diabetes. While the specific function in metabolism of each of the two RabGAPs remains to be determined, TBC1D1 emerges to be controlling exercise endurance and physical capacity, whereas TBC1D4 may rather be responsible for maintaining muscle insulin sensitivity, muscle contraction, and exercise. There is growing evidence that TBC1D1 also plays an important role in skeletal muscle development, since it has been found to be associated to meat production traits in several livestock species. In addition, TBC1D1 protein abundance in skeletal muscle is regulated by both, insulin receptor and insulin-like growth factor-1 (IGF-1) receptor signaling. This review focuses on the specific roles of the two key signaling factors TBC1D1 and TBC1D4 in skeletal muscle metabolism, development and exercise physiology.
\end{abstract}

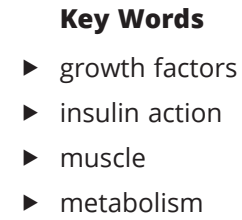

Journal of Molecular Endocrinology (2020) 64, R1-R19

\section{Skeletal muscle metabolism is crucial in controlling systemic metabolic flexibility and substrate utilization}

Metabolic flexibility represents the functional ability of an organism to accordingly adapt its energy substrate preference to alterations in energy demand. In the healthy state, postprandial insulin secretion leads to enhanced glucose oxidation, while lipid oxidation is inhibited (Chomentowski et al. 2011). Conversely, the insulin-resistant state is mostly characterized by reduced use of glucose as fuel, ectopic lipid accumulation and mitochondrial dysfunction (Morino et al. 2006, Petersen \& Shulman 2006).

In addition to the nutritional status such as fasting or postprandial conditions, physical activity requires a high degree of metabolic flexibility in order to ensure fuel availability and utilization in response to the increase in required energy (Egan \& Zierath 2013, Hawley et al. 2014).

Exercise is widely accepted as a useful means for both the prevention and treatment of metabolic diseases (Ostman et al. 2017). The underlying mechanisms of the beneficial impact of exercise on metabolic health are not yet fully understood. However, it is clear that regular physical activity has a strong influence on wholebody energy metabolism and, more specifically, on skeletal muscle substrate utilization (Madsen et al. 2015, Maillard et al. 2016, Lao et al. 2019).

Two putative key regulators of skeletal muscle substrate utilization are the closely related Rab guanosine 
triphosphatase-activating proteins (RabGAPs) TBC1D1 and TBC1D4, the latter also known as AKT substrate of $160 \mathrm{kDa}$, AS160 (Dokas et al. 2013, Chadt et al. 2015). This review focuses on the specific roles of the two signaling factors TBC1D1 and TBC1D4 in skeletal muscle function, development and exercise physiology.

\section{RabGAPs are key regulators of glucose metabolism in insulin-responsive tissues}

\section{RabGAPs control GLUT4-mediated glucose uptake into skeletal muscle and adipocytes}

Glucose uptake into insulin-responsive tissues such as skeletal muscle, adipose tissue and the heart is accomplished via the facilitative glucose transporter type 4 (GLUT4) (Joost et al. 2002, Thorens \& Mueckler 2010). In the basal state, that is, the absence of stimulatory elements like insulin or muscle contraction, GLUT4 is sequestered in intracellular storage vesicles (GSV) in the cytoplasm (Lauritzen 2013, Richter \& Hargreaves 2013). In response to insulin, GLUT4 translocation to the plasma membrane is accelerated via a phosphorylation cascade downstream of the insulin receptor (IR) involving activation of AKT (Foley et al. 2011). Likewise, GLUT4 translocation is increased as a result of multiple stimuli/ mechanisms like calcium-mediated processes, nitric oxide, reactive oxygen species and muscle contraction, the latter being associated with activation of AMP-activated kinase (AMPK) (Constable et al. 1988, Bryant et al. 2002, Tanaka et al. 2003, Horie et al. 2008, Angin et al. 2014).

The process of regulating the subcellular localization of GLUT4 is exceedingly complex and has been reviewed recently (Klip et al. 2019). A number of $21 \mathrm{kDa} R a b$ GTPases have been implicated to be involved in GLUT4 vesicle traffic, and their activation state, GTP-bound or GDP-bound, is presumably regulated by the RabGAPs TBC1D1 and TBC1D4 (Zerial \& McBride 2001). More than 60 different Rab proteins are described to date, exerting their main function in vesicle formation, transport, docking and fusion (Stenmark 2009, Pfeffer 2017). In adipocytes and muscular tissue, Rab8a, Rab10 and Rab14, all substrates for TBC1D1 and TBC1D4 in vitro, are associated with GLUT4 storage vesicles (Miinea et al. 2005, Roach et al. 2007, Reed et al. 2013).

While the exact function of the RabGAPs in the different steps of GLUT4 translocation is not fully understood, mutational analyses indicate that TBC1D1 and TBC1D4 exert an inhibitory effect on GLUT4 translocation that is relieved by phosphorylation at specific residues (Mafakheri et al. 2018a). Several serine (Ser) and threonine (Thr) phosphorylation sites (Tables 1, 2, 3 and 4) are described in both, TBC1D1 and TBC1D4, to be targeted by AKT and AMPK (Sano et al. 2003, Kramer et al. 2006, Roach et al. 2007, Chen et al. 2008). TBC1D1 is phosphorylated by AKT at Ser ${ }^{231}$ and Thr ${ }^{590}$ (Mafakheri et al. 2018b), whereas TBC1D4 has at least six phosphorylation motifs for AKT (Sano et al. 2003, Kramer et al. 2006).

Upon phosphorylation, 14-3-3 proteins bind to TBC1D1 and TBC1D4 (Ramm et al. 2006, Pehmoller et al. 2009). However, there is so far no direct evidence that either phosphorylation or 14-3-3 binding affects the RabGAP activity of the proteins in vitro (Mafakheri et al. $2018 b$ ). However, insertion of a constitutive 14-3-3 binding site into a phosphorylation-deficient dominantnegative TBC1D4 mutant reversed the inhibitory effect of the mutation on GLUT4 translocation in vivo (Ramm et al. 2006, Pehmoller et al. 2009). Presumably, phosphorylation-dependent recruitment of the RabGAPs to their cognate Rab GTPases may play an important role in regulating GLUT4 trafficking.

\section{RabGAPs are crucial regulators of whole-body glycemia}

Deficiency in only one of the two RabGAP leads to only moderate impairments in insulin sensitivity and glucose tolerance in rodents, indicating a possible compensatory function of the other respective isoform (Chadt et al. 2008, Lansey et al. 2012, Dokas et al. 2013, Wang et al. 2013). In double-deficient Tbc1d1/Tbc1d4-knockout mice, insulinas well as AICAR (5-Aminoimidazole-4-carboxamide ribonucleotide)-stimulated glucose uptake into skeletal muscle and adipose cells are almost completely abrogated and whole-body glycemia is affected to a greater extent compared to deficiency in only one of the RabGAPs (Chadt et al. 2015). Both muscle-specific Tbc1d4-knockout mice and homozygous allele carriers of a muscle-specific human loss-of-function mutation in TBC1D4 demonstrate elevated postprandial blood glucose levels, supporting the greater postulated role for this RabGAP in insulin action (Moltke et al. 2014, Xie et al. 2016). Interestingly, mutations in TBC1D1 have been linked to obesity-related traits in humans (Stone et al. 2006, Meyre et al. 2008) and mice (Chadt et al. 2008). Moreover, TBC1D1's role in beta-cell function may also influence fasting glucose homeostasis. Glucose-stimulated insulin secretion in isolated pancreatic islets from Tbc1d1-knockout mice was greater compared to WT littermates, suggesting 
Table 1 TBC1D1 phosphorylation sites.

\begin{tabular}{|c|c|c|c|c|}
\hline & Site & Target site & Tissue/cell line & Reference \\
\hline \multicolumn{5}{|c|}{ Insulin stimulation } \\
\hline Human & Thr596 & AKT & Skeletal muscle & Treebak et al. 2014 \\
\hline \multirow[t]{14}{*}{ Mouse } & Ser229 & AKT & C2C12 myotubes & Peck et al. 2009 \\
\hline & Ser231 & AMPK & In vitro, cell-free extracts & Mafakheri et al. $2018 a, b$ \\
\hline & Thr253 & & In vitro, TA muscle lysate & Taylor et al. 2008 \\
\hline & Ser 489 & AKT & C2C12 myotubes & Peck et al. 2009, Mafakheri et al. 2018a,b \\
\hline & Thr499 & AKT & C2C12 myotubes & Peck et al. 2009 \\
\hline & Ser501 & AKT & C2C12 myotubes & Peck et al. 2009 \\
\hline & Ser521 & & C2C12 myotubes & Peck et al. 2009 \\
\hline & Thr590 & AKT & In vitro, cell-free extracts & Mafakheri et al. $2018 a, b$ \\
\hline & Ser621 & & $\begin{array}{l}\text { In vitro, TA muscle lysate } \\
\mathrm{C} 2 \mathrm{C} 12 \text { myotubes }\end{array}$ & Taylor et al. 2008, Peck et al. 2009 \\
\hline & Ser660 & AMPK & $\begin{array}{l}\text { In vitro, TA muscle lysate } \\
\text { C2C12 myotubes }\end{array}$ & Taylor et al. 2008, Peck et al. 2009 \\
\hline & Ser697 & & C2C12 myotubes & Peck et al. 2009 \\
\hline & Ser698 & & C2C12 myotubes & Peck et al. 2009 \\
\hline & Ser699 & & C2C12 myotubes & Peck et al. 2009 \\
\hline & Thr 1218 & & C2C12 myotubes & Peck et al. 2009 \\
\hline \multicolumn{5}{|l|}{ Fasting } \\
\hline Human & Thr596 & & Skeletal muscle & Vendelbo et al. 2012 \\
\hline \multicolumn{5}{|c|}{ Skeletal muscle contraction (during) } \\
\hline \multirow[t]{5}{*}{ Human } & Ser237 & AMPK & Skeletal muscle cells & $\begin{array}{l}\text { Ramm et al. 2006, Chen et al. 2008, } \\
\text { Frosig et al. 2010, Treebak et al. } 2014\end{array}$ \\
\hline & Thr489 & AMPK & Bacterially expressed & Chen et al. 2008 \\
\hline & Thr596 & AMPK & Skeletal muscle cells & Treebak et al. 2014 \\
\hline & Ser 660 & AMPK & Skeletal muscle cells & Jessen et al. 2011, Treebak et al. 2014 \\
\hline & Ser700 & AMPK & Skeletal muscle cells & Treebak et al. 2014 \\
\hline \multirow[t]{5}{*}{ Mouse } & Ser237 & AMPK & In vitro, EDL muscle & Treebak et al. 2014 \\
\hline & Thr404 & AMPK & In vitro, cell-free extracts & Mafakheri et al. $2018 a, b$ \\
\hline & Thr596 & AMPK & In vitro, EDL muscle & Treebak et al. 2014 \\
\hline & Ser660 & AMPK & In vitro, EDL muscle & Treebak et al. 2014 \\
\hline & Ser 700 & AMPK & In vitro, EDL muscle & Treebak et al. 2014 \\
\hline \multicolumn{5}{|c|}{ AICAR stimulation } \\
\hline \multirow[t]{14}{*}{ Mouse } & $\operatorname{Ser}^{145}$ & & C2C12 myotubes & Peck et al. 2009 \\
\hline & $\operatorname{Ser}^{146}$ & & C2C12 myotubes & Peck et al. 2009 \\
\hline & Ser231 & & In vitro, TA muscle lysate & Taylor et al. 2008, Chen et al. 2016 \\
\hline & Thr253 & AMPK & In vitro, TA muscle lysate & Taylor et al. 2008 \\
\hline & Thr499 & AMPK & In vitro, TA muscle lysate & Taylor et al. 2008 \\
\hline & Ser501 & AKT & C2C12 myotubes & Peck et al. 2009 \\
\hline & Ser 521 & AKT+AMPK & C2C12 myotubes & Peck et al. 2009 \\
\hline & Ser559 & AMPK & C2C12 myotubes & Peck et al. 2009 \\
\hline & Ser560 & $\mathrm{AKT}+\mathrm{AMPK}$ & C2C12 myotubes & Peck et al. 2009 \\
\hline & Thr590 & AKT & C2C12 myotubes & Peck et al. 2009 \\
\hline & Ser608 & AKT+AMPK & C2C12 myotubes & Peck et al. 2009 \\
\hline & $\operatorname{Ser}^{621}$ & AKT & $\begin{array}{l}\text { In vitro, TA muscle lysate } \\
\mathrm{C} 2 \mathrm{C} 12 \text { myotubes }\end{array}$ & Taylor et al. 2008, Peck et al. 2009 \\
\hline & Ser660 & AMPK & $\begin{array}{l}\text { In vitro, TA muscle lysate } \\
\text { C2C12 myotubes }\end{array}$ & Taylor et al. 2008, Peck et al. 2009 \\
\hline & Ser700 & AMPK & $\begin{array}{l}\text { In vitro, TA muscle lysate } \\
\text { C2C12 myotubes }\end{array}$ & Taylor et al. 2008, Peck et al. 2009 \\
\hline Human & $\operatorname{Ser}^{473}$ & AKT & $\begin{array}{l}\text { Enhanced IGFBP-2 activation, activated } \\
\text { AKT signaling in skeletal muscle }\end{array}$ & Yau et al. 2014 \\
\hline \multicolumn{5}{|c|}{ IGF-1 stimulation } \\
\hline Human & Ser 473 & $\mathrm{AKT}$ & $\begin{array}{l}\text { Enhanced IGFBP-2 activation, activated } \\
\text { AKT signaling in skeletal muscle }\end{array}$ & Yau et al. 2014 \\
\hline \multirow[t]{3}{*}{ Mouse } & Thr172 & AKT & $\begin{array}{l}\text { IGF-1 and IGFBP-2 increase AMPK } \\
\text { phosphorylation at Thr172 in 3T3-L1 } \\
\text { adipocytes }\end{array}$ & Assefa et al. 2017 \\
\hline & Ser237 & AMPK & IGFBP-2 stimulation in 3T3-L1 adipocytes & Assefa et al. 2017 \\
\hline & Ser 473 & $\mathrm{AKT}$ & $\begin{array}{l}\text { IGF-1 and IGFBP-2 stimulate AKT Ser } 473 \text { in } \\
\text { 3T3-L1 adipocytes }\end{array}$ & Assefa et al. 2017 \\
\hline
\end{tabular}


Table 2 TBC1D4 phosphorylation sites.

\begin{tabular}{|c|c|c|c|c|}
\hline & Site & Target site & Tissue/cell line & Reference \\
\hline \multicolumn{5}{|l|}{ Insulin stimulation } \\
\hline \multirow[t]{6}{*}{ Human } & Ser 318 & & Skeletal muscle cells & Treebak et al. 2009, 2014 \\
\hline & Ser 341 & & Skeletal muscle cells & Treebak et al. 2009, 2014 \\
\hline & Ser 588 & & Skeletal muscle cells & Treebak et al. 2009 \\
\hline & Thr642 & & Skeletal muscle cells & Treebak et al. 2014 \\
\hline & Ser704 & & Skeletal muscle cells & Treebak et al. 2014 \\
\hline & Ser751 & & Skeletal muscle cells & Treebak et al. 2009 \\
\hline \multirow[t]{7}{*}{ Mouse } & Ser318 & & 3T3-L1 adipocytes & Sano et al. 2003 \\
\hline & Ser341 & & 3T3-L1 adipocytes & Sano et al. 2003 \\
\hline & Ser570 & AKT & 3T3-L1 adipocytes & Sano et al. 2003 \\
\hline & Ser588 & & 3T3-L1 adipocytes & Sano et al. 2003 \\
\hline & Thr642 & AKT & $\begin{array}{l}\text { 3T3-L1 adipocytes } \\
\text { Skeletal muscle }\end{array}$ & Sano et al. 2003, O’Neill et al. 2015 \\
\hline & Ser711 & & Soleus muscle & Treebak et al. 2010 \\
\hline & Thr751 & AKT & 3T3-L1 adipocytes & Sano et al. 2003 \\
\hline \multicolumn{5}{|c|}{ Insulin stimulation after contraction } \\
\hline \multirow[t]{7}{*}{ Human } & Ser 318 & & Skeletal muscle cells & $\begin{array}{l}\text { Pehmoller et al. 2009, Treebak et al. 2009, } \\
\text { Vind et al. } 2011\end{array}$ \\
\hline & Ser 341 & & Skeletal muscle cells & Treebak et al. 2009, 2014 \\
\hline & Ser588 & & Skeletal muscle cells & Treebak et al. 2009, 2014 \\
\hline & Ser704 & & Skeletal muscle cells & Treebak et al. 2014 \\
\hline & Ser751 & & Skeletal muscle cells & Treebak et al. 2009, 2014 \\
\hline & Thr642 & & Skeletal muscle cells & Treebak et al. 2009, 2014 \\
\hline & Ser666 & & Skeletal muscle cells & Treebak et al. 2014 \\
\hline \multicolumn{5}{|l|}{ Fasting } \\
\hline \multirow[t]{3}{*}{ Human } & Ser588 & & Skeletal muscle & Vendelbo et al. 2012 \\
\hline & Ser704 & & Skeletal muscle & Vendelbo et al. 2012 \\
\hline & Ser751 & & Skeletal muscle & Vendelbo et al. 2012 \\
\hline \multicolumn{5}{|c|}{ Skeletal muscle contraction (during) } \\
\hline \multirow[t]{7}{*}{ Human } & Ser 318 & AMPK & Skeletal muscle & Treebak et al. 2009 \\
\hline & Ser 341 & AMPK & Skeletal muscle & $\begin{array}{l}\text { Ramm et al. 2006, Chen et al. 2008, } \\
\text { Frosig et al. 2010, Treebak et al. } 2014\end{array}$ \\
\hline & Ser 588 & AMPK & Skeletal muscle & Treebak et al. 2009, 2014 \\
\hline & Thr 642 & AMPK & Skeletal muscle & Treebak et al. 2009, 2014 \\
\hline & Ser666 & AMPK & Skeletal muscle & Treebak et al. 2009 \\
\hline & Ser704 & AMPK & Skeletal muscle & Treebak et al. 2014 \\
\hline & Ser751 & AMPK & Skeletal muscle & Treebak et al. 2009, 2014 \\
\hline \multirow[t]{3}{*}{ Mouse } & Thr642 & & In vivo exercise, Gastrocnemius & Kramer et al. 2006 \\
\hline & Ser704 & & Ex vivo contraction, EDL & Kramer et al. 2006 \\
\hline & Ser711 & & In situ contraction TA & Treebak et al. 2010 \\
\hline Rat & Thr642 & & Epitrochlearis & Funai et al. 2009 \\
\hline \multicolumn{5}{|l|}{ Skeletal muscle contraction (post) } \\
\hline Human & Thr642 & & Skeletal muscle & Guerra et al. 2010 \\
\hline \multirow[t]{3}{*}{ Mouse } & Ser237 & AMPK & In vivo exercise, EDL muscle & Treebak et al. 2014 \\
\hline & Ser660 & AMPK & In vivo exercise, EDL muscle & Treebak et al. 2014 \\
\hline & Ser700 & AMPK & In vivo exercise, EDL muscle & Treebak et al. 2014 \\
\hline \multirow[t]{3}{*}{ Rat } & Ser 588 & & In vivo exercise, Epitrochlearis & $\begin{array}{l}\text { Schweitzer et al. 2012, Castorena et al. } \\
\text { 2014, Wang et al. } 2018\end{array}$ \\
\hline & Thr642 & & In vivo exercise, Epitrochlearis & $\begin{array}{l}\text { Funai et al. 2009, 2010, Schweitzer et al. } \\
\text { 2012, Castorena et al. 2014, Wang et al. } \\
2018\end{array}$ \\
\hline & Ser704 & & In vivo exercise, Epitrochlearis & Wang et al. 2018 \\
\hline \multicolumn{5}{|l|}{ AICAR stimulation } \\
\hline \multirow[t]{6}{*}{ Mouse } & Ser680 & & $\begin{array}{l}\text { In vitro gastrocnemius muscle } \\
\text { lysates }\end{array}$ & Treebak et al. 2010 \\
\hline & Ser711 & AMPK & $\begin{array}{l}\text { In vitro gastrocnemius muscle } \\
\text { lysates }\end{array}$ & Treebak et al. 2010 \\
\hline & & & Soleus muscle & \\
\hline & Ser 761 & & $\begin{array}{l}\text { In vitro gastrocnemius muscle } \\
\text { lysates }\end{array}$ & Treebak et al. 2010 \\
\hline & Ser764 & & $\begin{array}{l}\text { In vitro gastrocnemius muscle } \\
\text { lysates }\end{array}$ & Treebak et al. 2010 \\
\hline & Ser ${ }^{1135}$ & & $\begin{array}{l}\text { In vitro gastrocnemius muscle } \\
\text { lysates }\end{array}$ & Treebak et al. 2010 \\
\hline
\end{tabular}


Table 3 Cross-species reference of phosphorylation sites in TBC1D1.a

\begin{tabular}{|c|c|c|c|c|}
\hline Human & Mouse & Rat & Stimulus & Reference \\
\hline $\operatorname{Ser}^{145}$ & $\operatorname{Ser}^{145}$ & $\operatorname{Ser}^{145}$ & AICAR & Peck et al. 2009 \\
\hline $\operatorname{Ser}^{146}$ & $\operatorname{Ser}^{146}$ & Ser ${ }^{146}$ & AICAR & Peck et al. 2009 \\
\hline Ser235 & Ser229 & Ser229 & AKT & Chen et al. 2008, Peck et al. 2009 \\
\hline Ser 237 & Ser 231 & $\operatorname{Ser}^{231}$ & AMPK & $\begin{array}{l}\text { Chen et al. 2008, Jessen et al. 2011, Treebak et al. 2014, } \\
\text { Mafakheri et al. 2018a,b }\end{array}$ \\
\hline- & Thr253 & Thr 253 & AKT & Taylor et al. 2008 \\
\hline Thr410 & Thr404 & Thr 404 & AMPK & Mafakheri et al. 2018a,b \\
\hline- & Ser489 & Ser 489 & AKT & Peck et al. 2009, Mafakheri et al. 2018a,b \\
\hline Thr505 & Thr499 & Thr 499 & AKT & Peck et al. 2009 \\
\hline Ser 527 & Ser521 & Ser 521 & AKT/AICAR & Peck et al. 2009 \\
\hline Ser565 & Ser559 & Ser560 & AICAR & Peck et al. 2009 \\
\hline Ser565 & Ser560 & Ser 560 & AICAR & Peck et al. 2009 \\
\hline Thr596 & Thr590 & Thr 590 & AKT/Insulin/Exercise & Zhou et al. 2008, Jessen et al. 2011, Treebak et al. 2014 \\
\hline Ser667 & Ser621 & Ser621 & Insulin/AICAR & Taylor et al. 2008 \\
\hline Ser 667 & Ser660 & Ser 662 & Contraction/AICAR/AMPK & $\begin{array}{l}\text { Peck et al. 2006, 2009, Taylor et al. 2008, Jessen et al. 2011, } \\
\text { Treebak et al. 2014, Mafakheri et al. 2018a,b }\end{array}$ \\
\hline- & Ser700 & Ser702 & Contraction/AICAR/AMPK & Taylor et al. 2008, Treebak et al. 2014, Mafakheri et al. 2018a,b \\
\hline
\end{tabular}

that TBC1D1 is a negative regulator of insulin secretion (Paglialunga et al. 2017, Stermann et al. 2018).

\section{TBC1D1 and TBC1D4 are differentially expressed in insulin-target tissues, indicating complementary roles in signaling}

Despite a high degree of homology ( $\sim 4 \%$ overall amino acid identity, more than $76 \%$ in their functional GAP domain), the two RabGAPs show a differential expression pattern throughout insulin-responsive target tissues (Park et al. 2011). In mice, Tbc1d4 is mainly expressed in adipose tissues, oxidative skeletal muscle fibers (Soleus) and the heart (Wang et al. 2013). In contrast, Tbc1d1 is shown to be nearly absent in adipose tissue, but predominantly expressed in glycolytic skeletal muscle fibers (Extensor digitorum longus $=E D L$ ) (Chadt et al. 2008, An et al. 2010, Szekeres et al. 2012). In humans, however, no significant differences are described concerning TBC1D1 and TBC1D4 protein abundance in the different skeletal muscle subtypes (Jensen et al. 2012). It is postulated that TBC1D1 represents the more ancient RabGAP isoform, being present in invertebrates, while TBC1D4 evolved with the vertebrates (Chen et al. 2008). The basis of ongoing research has been the question concerning the specific role of each of the two isoforms and their respective contribution to substrate metabolism. Rodent studies indicate greater insulin-stimulated glucose

Table 4 Cross-species reference of phosphorylation sites in TBC1D4. ${ }^{\text {a }}$

\begin{tabular}{|c|c|c|c|}
\hline Human & Mouse & Rat & Stimulus \\
\hline Ser318 & Ser324 & Ser326 & AKT/Insulin/Exercise \\
\hline Ser341 & Ser 348 & Ser350 & AICAR/Insulin/Exercise \\
\hline Ser570 & Ser577 & Ser579 & Insulin/AKT \\
\hline Ser588 & Ser595 & Ser597 & Insulin/AKT/AICAR/Exercise \\
\hline Ser 591 & Ser598 & Ser600 & Contraction \\
\hline Ser609 & Ser616 & Ser618 & Contraction \\
\hline Thr642 & Thr649 & Thr651 & Insulin/AKT/AICAR/Exercise \\
\hline Ser666 & Ser673 & Ser675 & IGF-1 \\
\hline Ser673 & Ser680 & Ser675 & AICAR \\
\hline Ser704 & Ser 711 & Ser 713 & Insulin/AKT/AICAR/Exercise \\
\hline Thr751 & Thr758 & Ser760 & Insulin/AKT/AICAR/Exercise \\
\hline Ser 754 & Ser761 & Ser763 & AICAR \\
\hline Ser757 & Ser764 & Ser766 & AICAR \\
\hline Ser782 & Ser789 & Ser791 & Contraction \\
\hline Ser $^{1126}$ & Ser ${ }^{1135}$ & Ser ${ }^{1137}$ & AICAR \\
\hline
\end{tabular}

Reference

Sano et al. 2003, Geraghty et al. 2007, Treebak et al. 2009, 2014

Geraghty et al. 2007, Treebak et al. 2014

Sano et al. 2003, Geraghty et al. 2007

Sano et al. 2003, Geraghty et al. 2007, Treebak et al. 2009, 2014

Treebak et al. 2010

Treebak et al. 2010

Sano et al. 2003, Geraghty et al. 2007, Treebak et al. 2009, 2014

Geraghty et al. 2007

Treebak et al. 2010

Treebak et al. 2010, 2014

Sano et al. 2003, Geraghty et al. 2007, Treebak et al. 2009, 2014

Treebak et al. 2010

Treebak et al. 2010

Treebak et al. 2010

Treebak et al. 2010

aAccessions: TBC1D4: human (UniProt O60343), mouse (UniProt W8BYJ6), rat (RefSeq XP_017460442.1).

https://jme.bioscientifica.com

https://doi.org/10.1530/JME-19-0143 (c) 2020 Society for Endocrinology Published by Bioscientifica Ltd. Printed in Great Britain 
uptake in oxidative Soleus muscle compared to glycolytic EDL muscle (Bonen et al. 1981, James et al. 1985). A positive correlation between the relation of oxidative skeletal muscle and whole-body insulin sensitivity has been demonstrated in humans (Oberbach et al. 2006, Stuart et al. 2013). It is likely that human oxidative skeletal muscles are more important than glycolytic fibers for maintaining glucose homeostasis in response to insulin, since insulin-stimulated glucose transport in isolated human muscle strips was associated with the relative oxidative fiber content (Zierath et al. 1996). Indeed, a decreased proportion of oxidative skeletal muscle fibers has been found in individuals with metabolic syndrome, obesity and T2D (Marin et al. 1994, Gaster et al. 2001, Stuart et al. 2013). Differences in the insulin-mediated glucose metabolism between the muscle types are likely due to fiber type-specific expression and regulation of insulin signaling. Human oxidative skeletal muscle fibers exhibit greater protein levels of IR and GLUT4 and lower protein content of AKT, TBC1D1 and TBC1D4 compared to glycolytic fibers. The phosphorylation response to insulin is not different between both fiber types. These data suggest that human oxidative skeletal muscle fiber types have a higher glucose-handling capacity but a similar sensitivity for phosphoregulation by insulin, compared to glycolytic skeletal muscle fiber types (Albers et al. 2015).

\section{RabGAP deficiency leads to reduced GLUT4 protein abundance in insulin-target tissues}

Consistent with the fiber-type-specific RabGAP expression pattern, stimulation of glucose transport is impaired mainly in glycolytic skeletal muscle of Tbc1d1-deficient mice, whereas Tbc1d4-knockout mice display defective glucose uptake after stimulation in oxidative skeletal muscle (An etal. 2010, Chadt etal.2015). Moreover, insulinstimulated glucose transport is also substantially reduced in adipocytes from Tbc1d4-deficient mice (Chadt et al. 2015, Zhou et al. 2017). While the expected increase in basal glucose transport due to RabGAP depletion is shown for cultured 3T3-L1 adipocytes (Roach et al. 2007), this finding is not consistently validated in intact skeletal muscles or primary adipocytes (Chadt etal.2015). The main reason for this discrepancy is thought to be a concomitant decrease in GLUT4 protein abundance due to the RabGAP deficiency in the respective tissue type (Chadt et al. 2015, Hargett et al. 2016). The depletion of GLUT4 protein in insulin-target tissues occurs concomitantly with RabGAP deficiency in most studies. In mice reduced GLUT4 protein levels were mainly observed in glycolytic skeletal muscle types upon Tbc1d1 deficiency, whereas knockout of Tbc1d4 leads to a substantial reduction of GLUT4 abundance in oxidative skeletal muscle and the adipose tissue (Stockli et al. 2015). Moreover, human allele carriers of a nonsense p.Arg684Ter TBC1D4 variant demonstrate significantly reduced GLUT4 protein content in skeletal muscle (Moltke et al. 2014).

Of note, RabGAP deficiency-associated depletion of GLUT4 in skeletal muscle seems to occur as a result of posttranslational missorting processes since no alterations were detected on the mRNA level for Slc2a4 the gene encoding GLUT4 (Chadt et al. 2015, Stockli et al. 2015, Xie et al. 2016). The direct causal relationship between RabGAP deficiency and GLUT4 transporter reduction has been demonstrated by a study conducting a rescue experiment of GLUT4 abundance via overexpression of Tbc1d1 in skeletal muscle from Tbc1d1-knockout mice using in vivo electrotransfection (Stockli et al. 2015).

\section{GLUT4 depletion and altered subcellular distribution contribute to impaired glucose uptake in RabGAP-deficient skeletal muscle}

It has been speculated whether depletion in TBC1D1 or TBC1D4 specifically affects skeletal muscle and adipocyte glucose uptake solely by reducing GLUT4 protein abundance or whether trafficking of GLUT4-containing vesicles may be impaired as well. Cell-surface labeling of GLUT4 in skeletal muscle from Tbc1d1-deficient mice demonstrated that the amount of basal cell-surface GLUT4 in the $E D L$ was comparable with that of WT mice despite a lower abundance of total GLUT4. In contrast, upon insulin stimulation, cell-surface GLUT4 was also reduced compared to WT mice. However, taking the reduced amount of total GLUT4 transporter into account, a higher proportion of GLUT4 was present on the cell surface in the basal state, whereas the fraction of GLUT4 present on the plasma membrane in insulin-stimulated cells was relatively normal (Chadt et al. 2015). These data suggest that RabGAP-mediated impairments in glucose transport are mainly based on the reduction in GLUT4 abundance and only secondary on defects in transporter trafficking.

Both RabGAPs interact physically with the GLUT4 vesicle-resident protein insulin-regulated aminopeptidase (IRAP) (Peck et al. 2006). In the basal state, the cytosolic domain of IRAP binds to the second PTB domain of TBC1D4 and may keep the RabGAP in proximity to the GSVs. In response to insulin, TBC1D4 dissociates from IRAP and is released into the cytoplasm (Larance et al. 2005). Likewise, TBC1D1 interacts with IRAP in a phosphorylation- 
dependent manner. Immunoprecipitation of IRAP resulted in co-precipitation of TBC1D1, and this interaction was abolished after phosphorylation of TBC1D1 by AMPK or AKT, indicating that IRAP recruits the RabGAPs in a phosphorylation-dependent manner to GLUT4 vesicles (Mafakheri et al. 2018b). Interestingly, in skeletal muscle from double-deficient Tbc1d1/Tbc1d4-knockout mice. IRAP and GLUT4 proteins were reduced, whereas IRAP was not changed in the single knockouts (Chadt et al. 2015). Abrogation of TBC1D1 or TBC1D4 may result in the degradation of a subset of GLUT4-containing vesicles, indicating crosstalk in RabGAP-mediated trafficking.

\section{RabGAPs control lipid metabolism in skeletal muscle}

Skeletal muscle lipid utilization is of high relevance for the maintenance of a metabolic flexible state and thus may prevent insulin resistance and ectopic lipid accumulation. Accumulation of toxic lipid intermediates such as diacylglycerols (DAGs) and ceramides in skeletal muscle are known to impair muscular insulin sensitivity by inhibiting the insulin signaling cascade, a process described as 'lipotoxocity' (Ragheb et al. 2009, Boucher et al. 2014, Morales et al. 2017). Both TBC1D1 and TBC1D4 have been implicated to exert an important function in skeletal muscle lipid use; therefore, these two factors can be considered as signaling hubs between glucose and lipid metabolism. The following section summarizes the specific impact of the two RabGAPs on the diverse steps of skeletal muscle lipid metabolism, such as transport of fatty acids into the cell, fatty acid oxidation (FAO) and lipid accumulation.

\section{RabGAPs regulate FAO in skeletal muscle}

Tbc1d1-, Tbc1d4- and double-deficient mice preferably use lipids as energy substrate, indicated by a lower respiratory quotient (RQ) and thus elevated fatty acid oxidation in vivo. In addition, palmitate oxidation is increased in isolated Tbc1d1-deficient skeletal muscle ex vivo (Chadt et al. 2008, 2015, Dokas et al. 2013). This phenotype is speciesdependent and only present in mice, as the RQ is unaltered between Tbc1d4-deficient rats and WT littermates (Arias et al. 2019). Interestingly, isolated skeletal muscles from Tbc1d4-knockout mice demonstrated enhanced levels of FAO as well; however, whereas both glycolytic and oxidative skeletal muscles from Tbc1d1-deficient mice displayed enhanced basal FAO with no further increase by AICAR, FAO was also increased in glycolytic muscle from $T b c 1 d 4$-knockout which had normal glucose uptake, indicating independent regulation of glucose versus lipid utilization by RabGAPs (Chadt et al. 2015). Moreover, deficiency of both Tbc1d1 and Tbc1d4 did not exert additive effects on FAO as muscle from double-deficient Tbc1d1/Tbc1d4-knockout mice resembles each single knockout. These data indicate that (at least in glycolytic EDL muscle) TBC1D1 and TBC1D4 equally contribute to the effect on FAO, and the same target distal to both RabGAPs is likely to mediate the increased FAO.

A previous study demonstrated that overexpression of Tbc1d1 in mouse skeletal muscle by electrotransfection reduced the activity of $\beta$-HAD, a key enzyme in the $\beta$-oxidation pathway, resulting in impaired fatty acid oxidation (Maher et al. 2014). However, in skeletal muscle from $T b c 1 d 1$-knockout rats mitochondrial $\beta$-HAD activity was unaltered (Whitfield et al. 2017). The divergent results may be caused by compensatory mechanisms occurring during skeletal muscle development in the Tbc1d1knockout rats as overexpression of Tbc1d1 in mouse muscle was conducted in the adult state. Interestingly, the impact of RabGAPs on lipid metabolism is not restricted to skeletal muscle. In isolated mouse pancreatic islets Tbc1d 1 deficiency leads to both, enhanced insulin secretion and FAO ex vivo, presumably due to convergent RabGAP-mediated control of insulin vesicle and fatty acid transporter trafficking (Stermann et al. 2018).

To date, it is not clear whether RabGAPs have a direct regulatory connection to the oxidation of fatty acids or whether they exert their function exclusively on the level of fatty acid transport into the cell.

\section{RabGAPs may regulate the transport of fatty acids and lipid accumulation into the skeletal muscle}

Enhanced lipid use in RabGAP deficiency may result from altered trafficking and/or abundance of proteins involved in fatty acid transport and oxidation. Knockdown of Tbc1d4 in rat L6 myotubes and knockdown of Tbc1d1 in mouse $\mathrm{C} 2 \mathrm{C} 12$ myotubes increased long-chain fatty acid uptake (Chadt et al. 2008, Miklosz et al. 2016). Similarly, both Tbc1d1- and Tbc1d4-knockout mice and Tbc1d1knockout rats displayed increased fatty acid oxidation in isolated skeletal muscle (Chadt et al. 2015, Whitfield et al . 2017). However, while Tbc1d4-deficient L6 myotubes had increased expression levels of the fatty acid transporters fatty acid translocase (FAT/CD36) and fatty acid-binding protein (FABPpm), the abundance and plasma membrane localization of FAT/CD36 in skeletal muscle of Tbc1d1knockout rats was not altered (Miklosz et al. 2016, 
Whitfield et al. 2017). Thus, assuming a species-conserved mechanism present in RabGAP deficiency, alterations in FAT/CD36 may not explain the increased lipid use in the different knockout cells. Interestingly, however, knockdown of Tbc1d4 in mouse HL-1 cardiomyocytes resulted in redistribution of FAT/CD36 to the cell surface in a Rab8-dependent manner and overexpression of a phosphorylation-deficient dominant-negative $T b c 1 d 4$ mutant had the opposite effect (Samovski et al. 2012). Further studies should investigate an involvement of other additional fatty acid transporter proteins in RabGAP signaling, including FATP-1, FATP-4 or FABPpm which may contribute to the enhanced lipid utilization across species (Nickerson et al. 2009).

Silencing of Tbc1d4 after palmitate incubation in L6 myotubes has been demonstrated to decrease lipotoxic effects by a reduction in DAG and lipid levels (Table 1) (Miklosz et al. 2017). Moreover, the intramyocellular lipid content in these cells was decreased due to an elevated FAO rate (Miklosz et al. 2017). There is a relationship between fatty acid-binding protein 3 (FABP3) content in skeletal muscle and the development of obesity and/ or insulin resistance in mice. Mice with diet-induced obesity exhibit increased FABP3 content and fatty acid (FA) uptake in skeletal muscle. FABP3 may also contribute to TBC1D4 phosphorylation by insulin-dependent AKT activation in cells under palmitate-induced lipotoxic conditions (Kusudo et al. 2011). In contrast, an increase in muscle FABP3 with disturbed insulin action may result in i.m. fat deposition and could lead to insulin resistance (Kusudo et al. 2011). After a fasting period of $72 \mathrm{~h}, \mathrm{TBC} 1 \mathrm{D} 4$ phosphorylation of Ser ${ }^{588}, \mathrm{Ser}^{704}$ and Ser ${ }^{751}$ is decreased, whereas TBC1D1 phosphorylation of $\mathrm{Thr}^{596}$ is unaltered in human skeletal muscle (Vendelbo et al. 2012). This is associated with an increase in lipid content (Vendelbo et al. 2012). Interestingly, fasting did not impact phosphorylation of AMPK or AKT. Therefore it can be speculated that changes in skeletal muscle lipid content after fasting is mediated by reduced TBC1D4 signaling (Vendelbo et al. 2012).

\section{RabGAPs are crucial factors of exercise physiology}

\section{Exercise endurance is impaired in Tbc1d1 deficiency}

Contraction-stimulated GLUT4 translocation is thought to be insulin-independent, associated with AMPK activation and not reduced by insulin resistance (Marette et al. 1992, Richter \& Hargreaves 2013). Tbc1d1-deficient mice showed impaired exercise performance and endurance, reduced GLUT4 protein abundance and reduced glucose uptake in skeletal muscle (Dokas et al. 2013, Chadt et al. 2015, Stockli et al. 2015). The impairment in exercise endurance could not be attributed to changes in plasma non-esterified fatty acids (NEFAs) or muscle glycogen levels, since both are unaltered in knockout animals compared to WT littermates during exercise (Stockli et al. 2015). In Tbc1d4-deficient rats, voluntary physical activity was unaltered, even though GLUT4 protein abundance was decreased and AICAR-stimulated glucose uptake into skeletal muscle was reduced (Arias et al. 2019). However, exercise performance and exercise capacity were not determined in Tbc1d4-deficient rats or Tbc1d4-knockout mice. Thus, while the data support a role of TBC1D1 in determining exercise capacity, a possible involvement of TBC1D4 remains to be clarified.

Interestingly, a recent study confirmed reduced exercise performance and impaired glucose tolerance in Tbc1d1-deficient rats, despite no changes in GLUT4 abundance thus supporting a critical role of TBC1D1 in exercise response independent of GLUT4 levels (Whitfield et al. 2017).

The different GLUT4 levels in these studies may derive from species-dependent differences between rats and mice, as TBC1D1 and TBC1D4 abundance did not differ among multiple types of rat skeletal muscles (Castorena et al. 2011, Jensen et al. 2012). However, Whitfield et al. examined GLUT4 protein abundance in white and red quadriceps muscle, whereas others could confirm a reduced GLUT4 protein content in mouse $E D L$ muscle as well (Chen et al. 2008, Dokas et al. 2013, Stockli et al. 2015). Further studies are required to establish the relation of GLUT4 and TBC1D1 in different muscle types and species.

\section{Exercise potentiates insulin-stimulated RabGAP phosphorylation}

Human TBC1D1 is phosphorylated in response to contraction by AMPK at Ser ${ }^{237}, \mathrm{Thr}^{489}$, Thr ${ }^{596}, \mathrm{Ser}^{660}$ and Ser700 in vitro (Fig. 1 and Table 2) (Ramm et al. 2006, Chen et al. 2008, Frosig et al. 2010, Treebak et al. 2014). Recently, $\mathrm{Thr}^{404}$ (corresponding to $\mathrm{Thr}^{410}$ in humans) could be detected as a novel AMPK-dependent phosphorylation site (Table 4) (Mafakheri et al. 2018b). In humans, AMPK has been shown to phosphorylate TBC1D4 at Ser ${ }^{341}, \operatorname{Ser}^{588}$ and Ser ${ }^{751}$, in vitro (Fig. 1 and Tables 3, 5) (Ramm et al. 2006, Chen et al. 2008, Treebak et al. 2014).

In primary myotubes, in vitro electric pulse stimulation (EPS) mimics at least in part biological 
Table 5 Summary of RabGAP action in lipid metabolism.

\begin{tabular}{l}
\hline $\begin{array}{l}\text { Respiratory quotient (RQ) or } \\
\text { Respiratory Exchange Ratio (RER) }\end{array}$ \\
$\uparrow$ basal (EDL mouse muscle) \\
$\uparrow$ basal (Soleus mouse muscle) \\
$\leftrightarrow$ AICAR (EDL + Soleus mouse \\
muscles) \\
$\uparrow$ basal (EDL rat muscle) \\
$\uparrow$ in C2C12 myotubes \\
$\downarrow$ after palmitate incubation \\
$\downarrow$ after palmitate incubation \\
$\uparrow$ in C2C12 myotubes \\
$\leftrightarrow$ in C2C12 myotubes \\
$\leftrightarrow$ in C2C12 myotubes \\
$\uparrow$ in C2C12 myotubes \\
n.d. \\
n.d.
\end{tabular}

\begin{tabular}{l}
\hline TBC1D1-KO/Kd \\
\hline$\downarrow$ in mice \\
$\downarrow \leftrightarrow$ RER in rats
\end{tabular}

$\frac{\text { TBC1D4-KO/Kd }}{\downarrow \text { in mice }}$

$\uparrow$ basal (EDL mouse muscle)

$\leftrightarrow$ basal (Soleus mouse muscle)

$\leftrightarrow$ AICAR (EDL + Soleus mouse muscles) n.d.

Miklosz et al. 2016

Miklosz et al. 2017

Miklosz et al. 2017

Miklosz et al. 2016, Whitfield et al. 2017

Miklosz et al. 2016

Miklosz et al. 2016

Miklosz et al. 2016

Whitfield et al. 2017

Stermann et al. 2018 adaptions to endurance exercise (Nedachi et al. 2008). Similar to in vivo exercise, long-term EPS ( $\geq 24 \mathrm{~h}$, low frequency) induces glucose uptake and oxidation in response to AMPK activation via increased TBC1D1 phosphorylation (Nedachi et al. 2008). In contrast, shortterm EPS $(\leq 8 \mathrm{~h})$ treatment in fact leads to increased AMPK phosphorylation only at low frequency $(\leq 5 \mathrm{~Hz})$, whereas glucose uptake is increased at low and high frequency ( $\geq 30 \mathrm{~Hz}$ ) (Goto-Inoue et al. 2016, Nikolic et al. 2017). However, no changes in TBC1D1 phosphorylation were observed after short-term EPS at both frequencies (Nikolic et al. 2017). In human skeletal muscle from lean subjects, acute exercise followed by insulin stimulation potentiated phosphorylation of TBC1D4 at Ser ${ }^{318}$, $\operatorname{Ser}^{341}, \operatorname{Ser}^{588}, \operatorname{Ser}^{704}, \mathrm{Ser}^{751}$ and Thr ${ }^{642}$ (Vind et al. 2011, Pehmoller et al. 2012). In contrast, human primary myotubes that were exposed to in vitro contraction via EPS increased insulin-mediated phosphorylation of $\mathrm{Thr}^{642}$, Ser ${ }^{341}$ and $\mathrm{Ser}^{588}$, but could not potentiate the phosphorylation of $\mathrm{Ser}^{318}$ and Ser ${ }^{704}$. Therefore it is difficult to deduce additive stimulatory effects of insulin and contraction on TBC1D4 phosphorylation (Park et al. 2019). Myotubes from lean individuals that were first subjected to EPS displayed elevated TBC1D4 phosphorylation in response to insulin stimulation compared to obese persons. Therefore, in vitro contractile activity is able to potentiate insulin-stimulated TBC1D4 phosphorylation and improves insulin action, but to a lesser extent with cells from severely obese participants (Park et al. 2019).

\section{TBC1D1 signaling is important for glucose uptake during recovery after acute exercise training}

So far, it is not possible to deduce a specific role of each of the two RabGAPs in exercise signaling in skeletal muscle, since both exhibit phosphorylation sites that are exclusively phosphorylated in response to exercise (Treebak et al. 2014). In muscle-specific AMPK $\alpha 1 \alpha 2$ (mdAMPK $\alpha 1 \alpha 2$ )-knockout mice where both $\alpha$-subunits were abrogated, contraction-mediated glucose uptake into skeletal muscle was still normal, although TBC1D1 phosphorylation is severely impaired. This indicates that TBC1D1 may have a greater impact on glucose uptake during recovery after exercise than throughout the actual exercise training. However, in muscles from WT mice, TBC1D1 phosphorylation is increased $30 \mathrm{~min}$ and $1 \mathrm{~h}$ after in situ contraction and enhanced glucose uptake 


\begin{tabular}{|l|l|}
\hline Signaling pathway & Position \\
\hline Exercise & Human \\
Insulin & (Mouse) \\
IGF-1 & \\
\hline
\end{tabular}
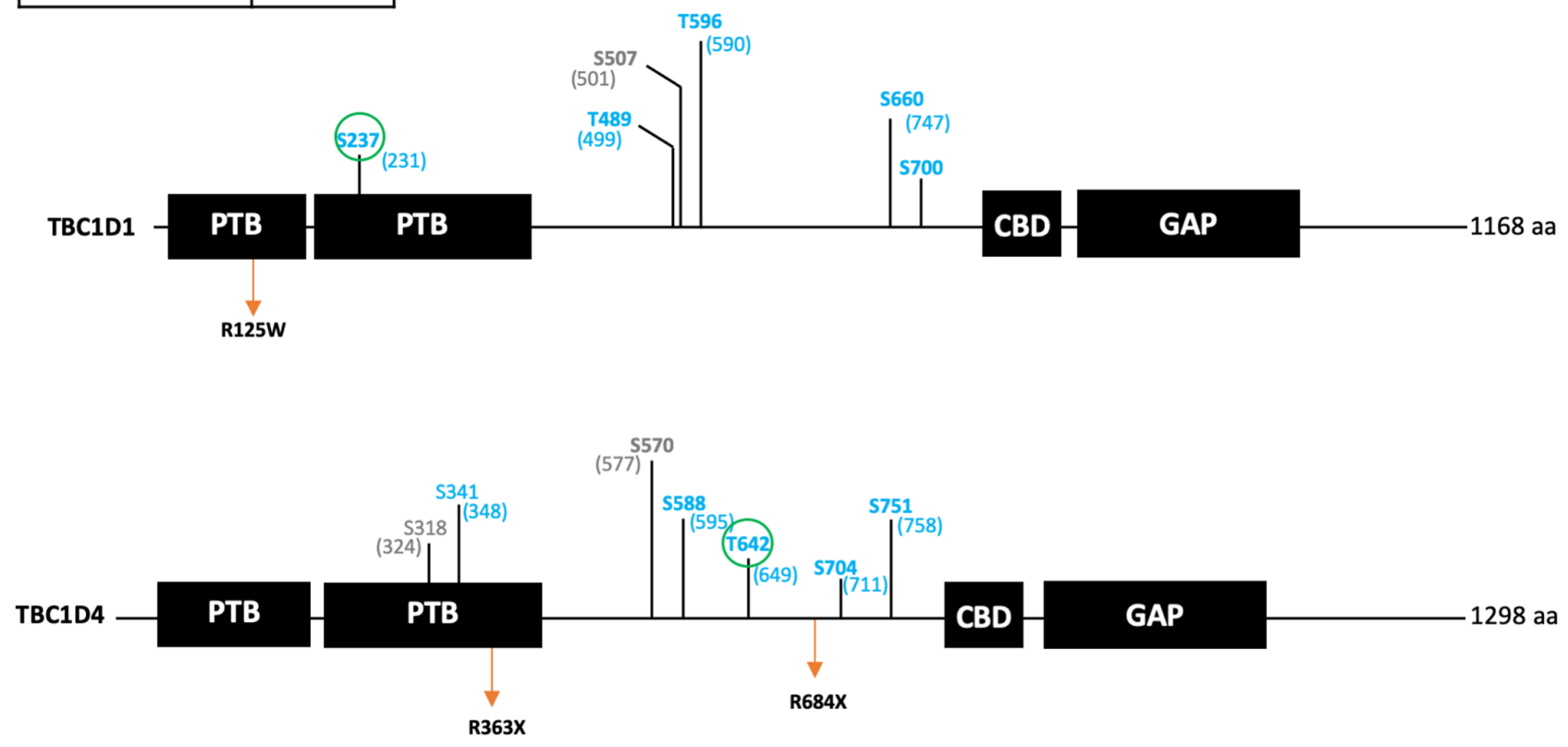

\section{Figure 1}

Domain structures and phosphorylation sites in TBC1D1 and TBC1D4. The two related proteins, TBC1D1 and TBC1D4, contain two amino-terminal PTB domains, a Ca+calmodulin-binding domain (CBD) and a catalytic RabGAP domain. Both TBC1D1 and TBC1D4 are phosphorylated at multiple Ser/Thr residues in response to insulin, IGF-1 and contraction/exercise by AKT and AMPK.

has been observed $1 \mathrm{~h}$ after the end of the contraction (Kjøbsted et al. 2019b).

\section{TBC1D4 enhances skeletal muscle insulin sensitivity and insulin-dependent glucose transport several hours after a single bout of exercise}

Genetic evidence suggests that TBC1D4 is required to enhance insulin sensitivity in skeletal muscle after exercise. Three hours after contraction or $6 \mathrm{~h}$ after AICAR stimulation, insulin-stimulated glucose uptake was increased in muscles from WT but not from Tbc1d4deficient mice (Kjøbsted et al. 2019a). Similarly, in rat skeletal muscle, TBC1D4 phosphorylation was enhanced after a single bout of exercise, resulting in increased insulin-dependent glucose transport for several hours post exercise (Arias et al. 2007). The enhanced insulin sensitivity in muscle after exercise was associated with increased insulin-stimulated phosphorylation of TBC1D4 but not TBC1D1 (Arias et al. 2007, Funai et al. 2009, Pehmoller et al. 2012, Kjøbsted et al. 2015, 2019b). Printed in Great Britain
Exercise has been shown to induce increased insulin-stimulated glucose uptake in skeletal muscle fibers type I, IIA, IIB, and IIBX but not IIX fibers, leading to the hypothesis whether exercise effects on TBC1D4 phosphorylation correspond to fiber typeselective exercise effects on insulin-stimulated glucose uptake (Cartee et al. 2016). Immediately after exercise, phosphorylation of TBC1D4 at $\mathrm{Ser}^{704}$ has been observed in each fiber type. However, in insulin-stimulated muscles $3.5 \mathrm{~h}$ post exercise, phosphorylation of TBC1D4 at $\mathrm{Thr}^{642}$ and $\mathrm{Ser}^{704}$ was only observed in skeletal muscle fiber type I, IIA, IIB, and IIBX, but not in IIX fibers. These results support the hypothesis that enhanced insulin-stimulated phosphorylation of TBC1D4 is linked to elevated insulinstimulated glucose uptake post exercise in a fiber typespecific manner (Wang et al. 2019).

\section{RabGAPs may regulate translocation of fatty acid transporter to the plasma membrane in response to contraction}

Muscle contraction induces FAT/CD36 translocation to the plasma membrane and increases import of 
NEFAs (Jordy \& Kiens 2014). In the resting state, a direct mechanistic link between AMPK activation and FAT/CD36 translocation has been proposed, since AICAR stimulation induced an increase in fatty acid uptake in skeletal muscle. More specifically, this AMPKinduced lipid oxidation is reduced in Cd36-knockout mice compared to WT littermates (Bonen et al. 2007). Moreover, FAT/CD36 translocation to the cell membrane is shown to be blunted after AICAR stimulation in transgenic AMPK kinase dead (AMPK KD) mice in nonexercising conditions, indicating that AMPK represents an important regulator of FAT/CD36 translocation under specific physiological conditions (Jeppesen et al. 2011). AMPK is a heterotrimeric protein that consists of catalytic $\alpha$-subunit and regulatory $\beta$ - and $\gamma$-subunits (Hardie \& Sakamoto 2006). The $\alpha$-subunit is responsible for AMPK activation due to phosphorylation of $\mathrm{Thr}^{172}$ residue (McBride \& Hardie 2009). AMPK $\alpha$ KD mice overexpress a kinase-dead mutant of AMPK $\alpha 2$-protein, leading to a suppressed $\mathrm{AMPK} \alpha 2$ activity. Interestingly, exercise induced an equal increase in cell-surface membrane FAT/ CD36 content in skeletal muscle from WT and AMPK $\alpha 2$ KD2 KDa mice (Jeppesen et al. 2011). This result supports an AMPK-independent mechanism in the FAT/CD36 translocation to the cell surface (Jeppesen et al. 2011). As direct AMPK phosphorylation targets, TBC1D1 and TBC1D4 represent a probable link between contractive stimulation and the uptake of fatty acids, for instance by regulating FAT/CD36 translocation.

Muscle contraction has a stimulatory effect on the translocation of FABPpm, FATP-1 and FATP-4 transporters as well (Jain et al. 2009), whereby FATP-1 translocation is also induced by insulin stimulation (Jain et al. 2015). Moreover, a decrease of both, FAT/CD36 and FABPpm protein abundance, is observed in a mouse model lacking both AMPK $\alpha 1$ and $-\alpha 2$ in skeletal muscle (AMPK $\alpha 1 \alpha 2$ mdKO) under sedentary and trained conditions (Fentz et al. 2015). In AMPK $\alpha 1 \alpha 2$ mdKO, TBC1D1 phosphorylation at the AMPK-dependent phosphorylation site $\operatorname{Ser}^{237}$ is blunted in response to contraction compared to WT littermates. These changes may contribute to an impairment of fatty acid cellular membrane transport and therefore TBC1D1 Ser ${ }^{237}$ may account to FAT/CD36 and FABPpm translocation and fatty acid metabolism in response to exercise (Fentz et al. 2015). These results indicate that in mice exercise- and contraction-induced fatty acid utilization in skeletal muscle is disturbed only when both AMPK $\alpha 1$ and AMPK $\alpha 2$ subunits are ablated, due to missing phosphorylation of TBC1D1 Ser ${ }^{237}$.
TBC1D4 signaling is involved in the exercise-mediated improvements on lipid-induced insulin resistance

As already mentioned in a chapter above, accumulation of toxic lipid intermediates such as DAGs in skeletal muscle impair muscular insulin sensitivity by inhibiting the insulin signaling cascade and consequently, GLUT4 translocation (Ragheb et al. 2009, Boucher et al. 2014, Morales et al. 2017). Exercise has a prophylactic effect on lipid-induced insulin resistance. Even a single bout of exercise has the ability to prevent lipid-induced impairments in whole-body glucose tolerance (Schenk $\&$ Horowitz 2007). The prophylactic effect of exercise on lipid-induced insulin resistance may involve TBC1D4 signaling. After lipid-induced insulin resistance in exercised human, prior exercise normalized insulinstimulated glucose uptake to the level that has been observed in the resting control leg that received saline injection (Pehmoller et al. 2012). Phosphorylation of TBC1D4 at Ser ${ }^{341}$ was impaired after lipid-induced insulin resistance in exercise human. The impairment could not be fully rescued after a single bout of exercise. On the other hand, neither prior exercise nor intralipid infusion affected basal and insulin-induced phosphorylation of TBC1D1 at Thr ${ }^{596}$ and Ser ${ }^{237}$ (Pehmoller et al. 2012). These results indicate that the signaling nexus TBC1D4 could play a potential role in the enhanced insulin action observed after a single bout of exercise (Treebak et al. 2009, Pehmoller et al. 2012).

\section{RabGAPs control skeletal muscle development}

\section{IGFBP-2 activation leads to enhanced insulin- stimulated glucose uptake in human skeletal myotubes via AKT and AMPK activation}

Insulin-like growth factor-binding protein-2 (IGFBP-2) belongs to a family of seven structurally binding proteins that regulate the bioavailability of IGF-1 (Russo et al. 2005). Reduced IGFBP-2 plasma levels are associated with higher fasting glucose levels and reduced insulin sensitivity in humans (Heald et al. 2006) and therefore IGFBP-2 may play a role in the development of insulin resistance and T2DM. Treatment of 3T3-L1 adipocytes with IGFBP-2 stimulates glucose uptake in a synergistic activation of AKT and AMPK with subsequently increased phosphorylation of TBC1D1 at the AMPK-dependent phosphorylation site Ser237 (Assefa et al. 2017). Neither AKT-dependent TBC1D1 phosphorylation sites, nor the phosphorylation 
state of TBC1D4 were measured. According to these data, it seems that IGFBP-2 activates the insulin-responsive phosphorylation sites of AKT at Ser ${ }^{473}$ and AMPK at Thr ${ }^{172}$ (Yau et al. 2014, Assefa et al. 2017).

\section{TBC1D1 signaling affects plasma IGF-1 levels}

IGF-1 exhibits structural homology to proinsulin and plays a critical role in proliferation and differentiation of skeletal muscle and adipocytes (Rinderknecht \& Humbel 1978, Smith et al. 1988). Insulin-like metabolic effects are induced by IGF-1 in both skeletal muscle and adipose tissue (Monzavi \& Cohen 2002). Mice that exhibit a Tbc1d1Ser231Ala knockin mutation that prevents AMPK-dependent phosphorylation of TBC1D1 at Ser 231 display higher plasma IGF-1 levels (Chen et al. 2016). This phosphorylation site is necessary to mediate 14-3-3 interaction with TBC1D1 in response to AMPK stimulation. 14-3-3 proteins interact with phosphorylated serine and threonine residues in TBC1D1 and TBC1D4 to support glucose uptake (Ramm et al. 2006). In Tbc1d1 $1^{\text {Ser231Ala }}$ knockin mice, where AMPK-dependent phosphorylation at $\operatorname{Ser}^{231}$ and subsequent 14-3-3 interaction are inhibited, glucose uptake in response to AICAR-stimulation is reduced (Chen et al. 2016). TBC1D1 may mediate IGF-1 secretion, as TBC1D1 is located on IGF-1 storage vesicles (Chen et al. 2016). In Tbc1d1Ser231Ala knockin mice, endocrinal and paracrinal/autocrinal IGF-1 secretion is enhanced in a Rab8a-dependent manner, resulting in a hypersecretion of IGF-1 that causes increased activation of the AKT-mammalian target of rapamycin (mTOR) pathway (Chen et al. 2016). These data provide evidence that TBC1D1 signaling interacts with the AKT-mTOR pathway via IGF-1 signaling (Fig. 2).

\section{RabGAPs are linked with skeletal muscle development via IR and IGF1R signal transduction}

Ablation of one or both RabGAPs in mice did not result in substantial changes in lean mass (Chadt et al. 2015). However, in states of strongly altered muscle mass changes in TBC1D1/TBC1D4 abundance and/or signaling have been observed. Both, insulin receptor (IR) and the IGF-1 receptor (IGF1R) signaling are playing a role in muscle growth and glucose homeostasis. Ablation of IR and IGF1R specifically in murine skeletal muscle (MIGIRKO) led to a $>60 \%$ decrease in muscle mass, severe muscle atrophy with spinal deformities and obvious kyphosis (O’Neill et al. 2015). MIGIRKO mice exhibit hypoglycemia under fasted conditions and increased basal glucose uptake due to increased expression and translocation of GLUT4, indicating that whole-body adaptions like increased basal glucose uptake into scWAT are responsible for normal glucose and insulin tolerance. It has been hypothesized that alternative tyrosine kinases may activate the insulin receptor substrate (IRS)-phosphoinositide 3-kinase (PI3K)AKT pathway in the absence of IR and IGF1R. Indeed, total EGF receptor (EGFR) levels are increased in MIGIRKO muscles, which may contribute to the observed increase in AKT phosphorylation. As a direct result of the elevated AKT activation, basal phosphorylation of TBC1D4 (Thr ${ }^{642}$ ) is increased in EDL and Soleus from fasted MIGIRKO mice (O'Neill et al. 2015). Despite an enhanced AMPK activation, TBC1D1 phosphorylation is not altered and TBC1D1 abundance is decreased (O'Neill et al. 2015). Increased AMPK phosphorylation might contribute to the decreased muscle mass in MIGIRKO mice (Bolster et al. 2002). Reduced TBC1D1 expression correlates with less muscle growth while increased TBC1D4 signaling seems to be responsible for enhanced basal glucose uptake in response to increased AKT activation in the basal state.

TBC1D4 is associated with skeletal muscle growth, as TBC1D4 signaling is enhanced upon inactivation of the myokine myostatin (Kocsis et al. 2017). Myostatin has been shown to be a negative regulator of muscle growth and development that inhibits proliferation and differentiation in myogenic cells as well as protein synthesis in existing muscle fibers (Chen \& Lee 2016). Mice that exhibit a loss of myostatin activity displayed hypermuscular changes and increased muscle weight. Moreover, phosphorylation of TBC1D4 (Thr ${ }^{642}$ ) is higher in comparison to WT littermates. However, neither phosphorylation state nor protein abundance of TBC1D1 were determined in mice exhibiting loss of myostatin activity. Therefore the hypermuscular effects could also be mediated by TBC1D1, and TBC1D4 is rather responsible for the improvements in glucose tolerance as AKT phosphorylation is increased as well (Kocsis et al. 2017).

Thus, even though both RabGAPs are associated with states of altered skeletal muscle growth, the causal contribution of TBC1D1 and TBC1D4 in skeletal muscle development remains to be determined. It is possible that RabGAP signaling primarily supports altered energy substrate metabolism of the growing muscle.

Moreover, while fiber type differences have a strong impact on skeletal muscle development (Schiaffino \& Reggiani 2011), the role of RabGAPs in fiber type-specific development remains to be established. 


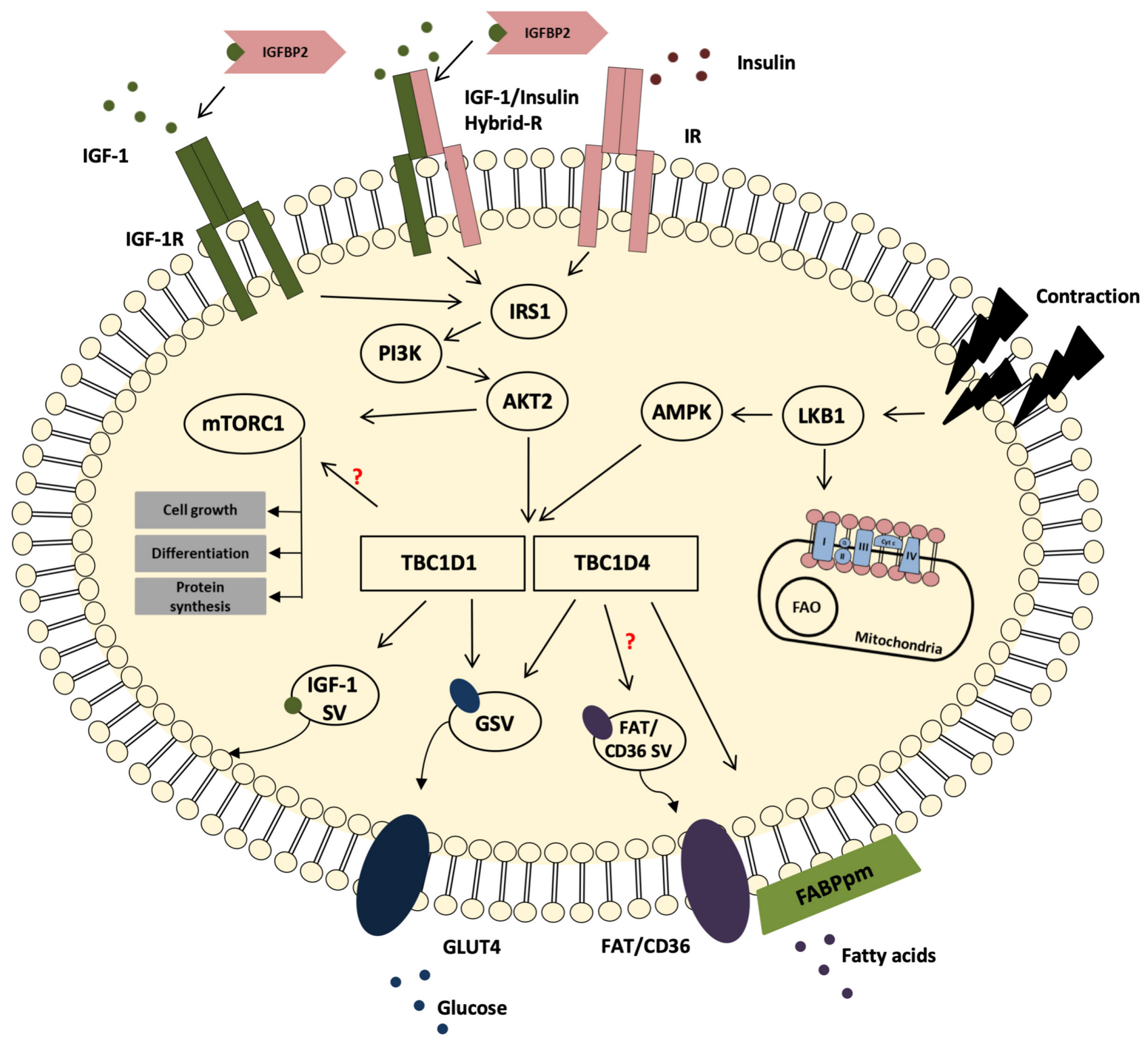

Figure 2

RabGAPs in skeletal muscle signaling. The RabGAPs TBC1D1 and TBC1D4 are crucial mediators in skeletal muscle signaling in response to insulin, IGF-1 and contraction. After binding of insulin or IGF-1 to its receptor, the IRS-PI3K-AKT signaling cascade is activated, leading to phosphorylation of TBC1D1 and TBC1D4 and subsequent translocation of GLUT4 from storage vesicles (GSV) to the plasma membrane. Phosphorylation of TBC1D4 may also regulate trafficking of fatty acid transporters FAT/CD36 and FATPpm. In response to contraction, LKB1 is also activated, leading to phosphorylation of AMPK and stimulation of fatty acid oxidation in mitochondria. TBC1D1 is associated with IGF-1 containing vesicles and might be involved in secretion of the hormone in skeletal muscle, where IGF-1 act in a paracrine/autocrine manner promoting skeletal muscle growth, differentiation and protein synthesis through the mTORC1 pathway (Geraghty et al. 2007, Taylor et al. 2008, Zhou et al. 2008, Peck et al. 2009, Funai et al. 2010, Guerra et al. 2010, Treebak et al. 2010, Jessen et al. 2011, Schweitzer et al. 2012, Castorena et al. 2014, Wang et al. 2018).

\section{TBC1D1 is associated with increased muscle mass} in livestock animals

From genetic studies of livestock it is known that TBC1D1 is closely associated with meat production and, as a consequence, with skeletal muscle development. A strong quantitative trait locus (QTL) for growth in chicken has been identified in the genomic region containing
TBC1D1 (Rubin et al. 2010). Moreover, specific SNPs in the chicken TBC1D1 gene are associated with body weight (g.69340070CNT) and leg muscle weight (g.69307744CNT) (Wang et al. 2014). During chicken development, Tbc1d1 mRNA increases in thigh muscle until week 10 and is unaltered afterward, whereas in breast muscle Tbc1d1 mRNA expression is generally unaltered during chicken development (Peng et al. 2015). These differences may occur 
due to the physiology of muscle composition, as the chicken thigh is more oxidative, compared to the more glycolytic breast and therefore the latter more closely resembles the glycolytic EDL (Williamson et al. 2006). However, muscle weight has not been measured in the latter study; therefore, it is unclear whether Tbc1d1 mRNA expression equally correlates with growth in different types of muscle. In addition, a variant (g.219G $>A$ ) in the porcine TBC1D1 gene was associated with meat production in Italian Large White and Italian Duroc breeds, whereas another variant (c.214G $>$ A) was associated with postnatal growth traits in rabbits (Fontanesi et al. 2011, 2012, Yang et al. 2013). The latter studies however did not resolve the contribution of the variants to fat deposition and muscle mass. Despite the genetic evidence for an association of TBC1D1 with muscle growth, it remains to be further investigated whether TBC1D1 signaling induces muscle growth or hypertrophy activates TBC1D1 expression and signaling.

\section{Conclusion}

In this review, we summarize studies of the two RabGAPs TBC1D1 and TBC1D4 in skeletal muscle function, development and exercise physiology. The importance of TBC1D1 and TBC1D4 for GLUT4-mediated glucose uptake is well established. However, the mechanisms how these RabGAPs regulate lipid utilization in skeletal muscle are now well understood. In analogy to the regulation of glucose transporters, TBC1D1 and TBC1D4 might regulate RabGTPase-dependent trafficking of fatty acid transporters.

While both RabGAPs maybe involved in the exercisestimulated glucose uptake where deficiency impairs exercise endurance, the individual contribution of each RabGAP is not yet known. TBC1D1 may have a greater impact on glucose uptake during recovery after exercise than throughout the actual exercise training, whereas there is genetic evidence of TBC1D4 signaling to enhance muscle insulin sensitivity following contraction. Moreover, genetic cross species studies indicate that TBC1D1, the evolutionary more ancient isoform, is closely associated with meat production and thus muscle development, implicating an essential function of this RabGAP in muscle biology.

In summary, the contributions of each of the two RabGAPs to skeletal muscle function and development are complex and not restricted to purely metabolic signaling pathways. There is rising evidence for a diversified role of TBC1D1 and TBC1D4 in the distinct processes, and it is clear that up to today, we are far from understanding the whole picture.

\section{Declaration of interest}

The authors declare that there is no conflict of interest that could be perceived as prejudicing the impartiality of this review.

\section{Funding}

This work was supported by the Ministry of Innovation, Science and Research of the State of North Rhine-Westphalia (MIWF NRW) and the German Federal Ministry of Health (BMG) and was funded in part by grants from the Deutsche Forschungsgemeinschaft (SFB1116 to H A; $\mathrm{CH} 1659$ to A C) and the EFSD/Novo Nordisk program (to $\mathrm{H} \mathrm{A}$ ).

\section{Acknowledgement}

The authors would like to thank Dr Samaneh Eickelschulte for support in preparing the manuscript.

\section{References}

Albers PH, Pedersen AJ, Birk JB, Kristensen DE, Vind BF, Baba O, Nohr J, Hojlund K \& Wojtaszewski JF 2015 Human muscle fiber type-specific insulin signaling: impact of obesity and type 2 diabetes. Diabetes 64 485-497. (https://doi.org/10.2337/db14-0590)

An D, Toyoda T, Taylor EB, Yu H, Fujii N, Hirshman MF \& Goodyear LJ 2010 TBC1D1 regulates insulin- and contraction-induced glucose transport in mouse skeletal muscle. Diabetes 59 1358-1365. (https:// doi.org/10.2337/db09-1266)

Angin Y, Schwenk RW, Nergiz-Unal R, Hoebers N, Heemskerk JW, Kuijpers MJ, Coumans WA, van Zandvoort MA, Bonen A, Neumann D, et al. 2014 Calcium signaling recruits substrate transporters GLUT4 and CD36 to the sarcolemma without increasing cardiac substrate uptake. American Journal of Physiology: Endocrinology and Metabolism 307 E225-E236. (https://doi.org/10.1152/ ajpendo.00655.2013)

Arias EB, Kim J, Funai K \& Cartee GD 2007 Prior exercise increases phosphorylation of Akt substrate of $160 \mathrm{kDa}$ (AS160) in rat skeletal muscle. American Journal of Physiology: Endocrinology and Metabolism 292 E1191-E1200. (https://doi.org/10.1152/ajpendo.00602.2006)

Arias EB, Zheng X, Agrawal S \& Cartee GD 2019 Whole body glucoregulation and tissue-specific glucose uptake in a novel Akt substrate of 160 kDa knockout rat model. PLOS ONE 14 e0216236. (https://doi.org/10.1371/journal.pone.0216236)

Assefa B, Mahmoud AM, Pfeiffer AFH, Birkenfeld AL, Spranger J \& Arafat AM 2017 Insulin-like growth factor (IGF) binding protein-2, independently of IGF-1, induces GLUT-4 translocation and glucose uptake in 3T3-L1 adipocytes. Oxidative Medicine and Cellular Longevity 2017 3035184. (https://doi.org/10.1155/2017/3035184)

Bolster DR, Crozier SJ, Kimball SR \& Jefferson LS 2002 AMP-activated protein kinase suppresses protein synthesis in rat skeletal muscle through down-regulated mammalian target of rapamycin (mTOR) signaling. Journal of Biological Chemistry 277 23977-23980. (https:// doi.org/10.1074/jbc.C200171200)

Bonen A, Tan MH \& Watson-Wright WM 1981 Insulin binding and glucose uptake differences in rodent skeletal muscles. Diabetes 30 702-704. (https://doi.org/10.2337/diab.30.8.702)

Bonen A, Han XX, Habets DD, Febbraio M, Glatz JF \& Luiken JJ 2007 A null mutation in skeletal muscle FAT/CD36 reveals its essential role in insulin- and AICAR-stimulated fatty acid metabolism. American Journal of Physiology: Endocrinology and Metabolism 292 E1740-E1749. (https://doi.org/10.1152/ajpendo.00579.2006)

Boucher J, Kleinridders A \& Kahn CR 2014 Insulin receptor signaling in normal and insulin-resistant states. Cold Spring Harbor Perspectives in Biology 6 a009191. (https://doi.org/10.1101/cshperspect.a009191) 
Bryant NJ, Govers R \& James DE 2002 Regulated transport of the glucose transporter GLUT4. Nature Reviews: Molecular Cell Biology 3 267-277. (https://doi.org/10.1038/nrm782)

Cartee GD, Arias EB, Yu CS \& Pataky MW 2016 Novel single skeletal muscle fiber analysis reveals a fiber type-selective effect of acute exercise on glucose uptake. American Journal of Physiology: Endocrinology and Metabolism 311 E818-E824. (https://doi. org/10.1152/ajpendo.00289.2016)

Castorena CM, Mackrell JG, Bogan JS, Kanzaki M \& Cartee GD 2011 Clustering of GLUT4, TUG, and RUVBL2 protein levels correlate with myosin heavy chain isoform pattern in skeletal muscles, but AS160 and TBC1D1 levels do not. Journal of Applied Physiology 111 1106-1117. (https://doi.org/10.1152/japplphysiol.00631.2011)

Castorena CM, Arias EB, Sharma N \& Cartee GD 2014 Postexercise improvement in insulin-stimulated glucose uptake occurs concomitant with greater AS160 phosphorylation in muscle from normal and insulin-resistant rats. Diabetes 63 2297-2308. (https:// doi.org/10.2337/db13-1686)

Chadt A, Leicht K, Deshmukh A, Jiang LQ, Scherneck S, Bernhardt U, Dreja T, Vogel H, Schmolz K, Kluge R, et al. 2008 Tbc1d1 mutation in lean mouse strain confers leanness and protects from diet-induced obesity. Nature Genetics 40 1354-1359. (https://doi.org/10.1038/ ng.244)

Chadt A, Immisch A, de Wendt C, Springer C, Zhou Z, Stermann T, Holman GD, Loffing-Cueni D, Loffing J, Joost HG, et al. 2015 Deletion of both Rab-GTPase-activating proteins TBC1D1 and TBC1D4 in mice eliminates insulin- and AICAR-stimulated glucose transport [corrected]. Diabetes 64 746-759. (https://doi.org/10.2337/ db14-0368)

Chen PR \& Lee K 2016 INVITED REVIEW: Inhibitors of myostatin as methods of enhancing muscle growth and development. Journal of Animal Science 94 3125-3134. (https://doi.org/10.2527/jas.20160532)

Chen S, Murphy J, Toth R, Campbell DG, Morrice NA \& Mackintosh C 2008 Complementary regulation of TBC1D1 and AS160 by growth factors, insulin and AMPK activators. Biochemical Journal 409 449-459. (https://doi.org/10.1042/BJ20071114)

Chen L, Chen Q, Xie B, Quan C, Sheng Y, Zhu S, Rong P, Zhou S, Sakamoto K, MacKintosh C, et al. 2016 Disruption of the AMPKTBC1D1 nexus increases lipogenic gene expression and causes obesity in mice via promoting IGF1 secretion. PNAS 113 7219-7224 (https://doi.org/10.1073/pnas.1600581113)

Chomentowski P, Coen PM, Radikova Z, Goodpaster BH \& Toledo FG 2011 Skeletal muscle mitochondria in insulin resistance: differences in intermyofibrillar versus subsarcolemmal subpopulations and relationship to metabolic flexibility. Journal of Clinical Endocrinology and Metabolism 96 494-503. (https://doi.org/10.1210/jc.2010-0822)

Constable SH, Favier RJ, Cartee GD, Young DA \& Holloszy JO 1988 Muscle glucose transport: interactions of in vitro contractions, insulin, and exercise. Journal of Applied Physiology 64 2329-2332. (https://doi.org/10.1152/jappl.1988.64.6.2329)

Dokas J, Chadt A, Nolden T, Himmelbauer H, Zierath JR, Joost HG \& Al-Hasani H 2013 Conventional knockout of Tbc1d1 in mice impairs insulin- and AICAR-stimulated glucose uptake in skeletal muscle. Endocrinology 154 3502-3514. (https://doi.org/10.1210/en.2012-2147)

Egan B \& Zierath JR 2013 Exercise metabolism and the molecular regulation of skeletal muscle adaptation. Cell Metabolism 17 162-184. (https://doi.org/10.1016/j.cmet.2012.12.012)

Fentz J, Kjøbsted R, Birk JB, Jordy AB, Jeppesen J, Thorsen K, Schjerling P, Kiens B, Jessen N, Viollet B, et al. 2015 AMPKalpha is critical for enhancing skeletal muscle fatty acid utilization during in vivo exercise in mice. FASEB Journal 29 1725-1738. (https://doi. org/10.1096/fj.14-266650)

Foley K, Boguslavsky S \& Klip A 2011 Endocytosis, recycling, and regulated exocytosis of glucose transporter 4. Biochemistry $\mathbf{5 0}$ 3048-3061. (https://doi.org/10.1021/bi2000356)
Fontanesi L, Colombo M, Tognazzi L, Scotti E, Buttazzoni L, Dall'Olio S, Davoli R \& Russo V 2011 The porcine TBC1D1 gene: mapping, SNP identification, and association study with meat, carcass and production traits in Italian heavy pigs. Molecular Biology Reports $\mathbf{3 8}$ 1425-1431. (https://doi.org/10.1007/s11033-010-0247-3)

Fontanesi L, Galimberti G, Calo DG, Fronza R, Martelli PL, Scotti E, Colombo M, Schiavo G, Casadio R, Buttazzoni L, et al. 2012 Identification and association analysis of several hundred single nucleotide polymorphisms within candidate genes for back fat thickness in Italian Large White pigs using a selective genotyping approach. Journal of Animal Science 90 2450-2464. (https://doi. org/10.2527/jas.2011-4797)

Frosig C, Pehmoller C, Birk JB, Richter EA \& Wojtaszewski JF 2010 Exercise-induced TBC1D1 Ser237 phosphorylation and 14-3-3 protein binding capacity in human skeletal muscle. Journal of Physiology 588 4539-4548. (https://doi.org/10.1113/ jphysiol.2010.194811)

Funai K, Schweitzer GG, Sharma N, Kanzaki M \& Cartee GD 2009 Increased AS160 phosphorylation, but not TBC1D1 phosphorylation, with increased postexercise insulin sensitivity in rat skeletal muscle. American Journal of Physiology: Endocrinology and Metabolism 297 E242-E251. (https://doi.org/10.1152/ajpendo.00194.2009)

Funai K, Schweitzer GG, Castorena CM, Kanzaki M \& Cartee GD 2010 In vivo exercise followed by in vitro contraction additively elevates subsequent insulin-stimulated glucose transport by rat skeletal muscle. American Journal of Physiology: Endocrinology and Metabolism 298 E999-1010. (https://doi.org/10.1152/ajpendo.00758.2009)

Gaster M, Staehr P, Beck-Nielsen H, Schroder HD \& Handberg A 2001 GLUT4 is reduced in slow muscle fibers of type 2 diabetic patients: is insulin resistance in type 2 diabetes a slow, type 1 fiber disease? Diabetes 50 1324-1329. (https://doi.org/10.2337/diabetes.50.6.1324)

Geraghty KM, Chen S, Harthill JE, Ibrahim AF, Toth R, Morrice NA, Vandermoere F, Moorhead GB, Hardie DG \& MacKintosh C 2007 Regulation of multisite phosphorylation and 14-3-3 binding of AS160 in response to IGF-1, EGF, PMA and AICAR. Biochemical Journal 407 231-241. (https://doi.org/10.1042/BJ20070649)

Goto-Inoue N, Tamura K, Motai F, Ito M, Miyata K, Manabe Y \& Fujii NL 2016 A fragmented form of annexin A1 is secreted from C2C12 myotubes by electric pulse-induced contraction. Molecular and Cellular Biochemistry 411 173-180. (https://doi.org/10.1007/ s11010-015-2579-8)

Guerra B, Guadalupe-Grau A, Fuentes T, Ponce-Gonzalez JG, MoralesAlamo D, Olmedillas H, Guillen-Salgado J, Santana A \& Calbet JA 2010 SIRT1, AMP-activated protein kinase phosphorylation and downstream kinases in response to a single bout of sprint exercise: influence of glucose ingestion. European Journal of Applied Physiology 109 731-743. (https://doi.org/10.1007/s00421-010-1413-y)

Hardie DG \& Sakamoto K 2006 AMPK: a key sensor of fuel and energy status in skeletal muscle. Physiology 21 48-60. (https://doi. org/10.1152/physiol.00044.2005)

Hargett SR, Walker NN \& Keller SR 2016 Rab GAPs AS160 and Tbc1d1 play nonredundant roles in the regulation of glucose and energy homeostasis in mice. American Journal of Physiology: Endocrinology and Metabolism 310 E276-E288. (https://doi.org/10.1152/ ajpendo.00342.2015)

Hawley JA, Hargreaves M, Joyner MJ \& Zierath JR 2014 Integrative biology of exercise. Cell 159 738-749. (https://doi.org/10.1016/j. cell.2014.10.029)

Heald AH, Kaushal K, Siddals KW, Rudenski AS, Anderson SG \& Gibson JM 2006 Insulin-like growth factor binding protein-2 (IGFBP2) is a marker for the metabolic syndrome. Experimental and Clinical Endocrinology and Diabetes 114 371-376. (https://doi. org/10.1055/s-2006-924320)

Horie T, Ono K, Nagao K, Nishi H, Kinoshita M, Kawamura T, Wada H, Shimatsu A, Kita T \& Hasegawa K 2008 Oxidative stress induces GLUT4 translocation by activation of PI3-K/Akt and dual AMPK 
kinase in cardiac myocytes. Journal of Cellular Physiology $\mathbf{2 1 5}$ 733-742. (https://doi.org/10.1002/jcp.21353)

Jain SS, Chabowski A, Snook LA, Schwenk RW, Glatz JF, Luiken JJ \& Bonen A 2009 Additive effects of insulin and muscle contraction on fatty acid transport and fatty acid transporters, FAT/CD36, FABPpm, FATP1, 4 and 6. FEBS Letters $\mathbf{5 8 3}$ 2294-2300. (https://doi. org/10.1016/j.febslet.2009.06.020)

Jain SS, Luiken JJ, Snook LA, Han XX, Holloway GP, Glatz JF \& Bonen A 2015 Fatty acid transport and transporters in muscle are critically regulated by Akt2. FEBS Letters $\mathbf{5 8 9}$ 2769-2775. (https://doi. org/10.1016/j.febslet.2015.08.010)

James DE, Jenkins AB \& Kraegen EW 1985 Heterogeneity of insulin action in individual muscles in vivo: euglycemic clamp studies in rats. American Journal of Physiology 248 E567-E574. (https://doi. org/10.1152/ajpendo.1985.248.5.E567)

Jensen TE, Leutert R, Rasmussen ST, Mouatt JR, Christiansen ML, Jensen BR \& Richter EA 2012 EMG-normalised kinase activation during exercise is higher in human gastrocnemius compared to soleus muscle. PLOS ONE 7 e31054. (https://doi.org/10.1371/journal. pone.0031054)

Jeppesen J, Albers PH, Rose AJ, Birk JB, Schjerling P, Dzamko N, Steinberg GR \& Kiens B 2011 Contraction-induced skeletal muscle FAT/CD36 trafficking and FA uptake is AMPK independent. Journal of Lipid Research 52 699-711. (https://doi.org/10.1194/jlr.M007138)

Jessen N, An D, Lihn AS, Nygren J, Hirshman MF, Thorell A \& Goodyear LJ 2011 Exercise increases TBC1D1 phosphorylation in human skeletal muscle. American Journal of Physiology: Endocrinology and Metabolism 301 E164-E171. (https://doi.org/10.1152/ ajpendo.00042.2011)

Joost HG, Bell GI, Best JD, Birnbaum MJ, Charron MJ, Chen YT, Doege H, James DE, Lodish HF, Moley KH, et al. 2002 Nomenclature of the GLUT/SLC2A family of sugar/polyol transport facilitators. American Journal of Physiology: Endocrinology and Metabolism 282 E974-E976. (https://doi.org/10.1152/ajpendo.00407.2001)

Jordy AB \& Kiens B 2014 Regulation of exercise-induced lipid metabolism in skeletal muscle. Experimental Physiology 99 1586-1592. (https://doi.org/10.1113/expphysiol.2014.082404)

Kjøbsted R, Treebak JT, Fentz J, Lantier L, Viollet B, Birk JB, Schjerling P, Bjornholm M, Zierath JR \& Wojtaszewski JF 2015 Prior AICAR stimulation increases insulin sensitivity in mouse skeletal muscle in an AMPK-dependent manner. Diabetes 64 2042-2055. (https://doi. org/10.2337/db14-1402)

Kjøbsted R, Chadt A, Jorgensen NO, Kido K, Larsen JK, de Wendt C, Al-Hasani H \& Wojtaszewski JFP 2019a TBC1D4 is necessary for enhancing muscle insulin sensitivity in response to AICAR and contraction. Diabetes 68 1756-1766. (https://doi.org/10.2337/db180769)

Kjøbsted R, Roll JLW, Jørgensen NO, Birk JB, Foretz M, Viollet B, Chadt A, Al-Hasani H \& Wojtaszewski JFP 2019b AMPK and TBC1D1 regulate muscle glucose uptake after, but not during, exercise and contraction. Diabetes 68 1427-1440. (https://doi.org/10.2337/db190050)

Klip A, McGraw TE \& James DE 2019 Thirty sweet years of GLUT4. Journal of Biological Chemistry 294 11369-11381. (https://doi. org/10.1074/jbc.REV119.008351)

Kocsis T, Trencsenyi G, Szabo K, Baan JA, Muller G, Mendler L, Garai I, Reinauer H, Deak F, Dux L, et al. 2017 Myostatin propeptide mutation of the hypermuscular compact mice decreases the formation of myostatin and improves insulin sensitivity. American Journal of Physiology: Endocrinology and Metabolism 312 E150-E160. (https://doi.org/10.1152/ajpendo.00216.2016)

Kramer HF, Witczak CA, Fujii N, Jessen N, Taylor EB, Arnolds DE, Sakamoto K, Hirshman MF \& Goodyear LJ 2006 Distinct signals regulate AS160 phosphorylation in response to insulin, AICAR, and contraction in mouse skeletal muscle. Diabetes 55 2067-2076. (https://doi.org/10.2337/db06-0150)
Kraniou Y, Cameron-Smith D, Misso M, Collier G \& Hargreaves M 2000 Effects of exercise on GLUT-4 and glycogenin gene expression in human skeletal muscle. Journal of Applied Physiology 88 794-796. (https://doi.org/10.1152/jappl.2000.88.2.794)

Kusudo T, Kontani Y, Kataoka N, Ando F, Shimokata H \& Yamashita H 2011 Fatty acid-binding protein 3 stimulates glucose uptake by facilitating AS160 phosphorylation in mouse muscle cells. Genes to Cells 16 681-691. (https://doi.org/10.1111/j.1365-2443.2011.01517.x)

Lansey MN, Walker NN, Hargett SR, Stevens JR \& Keller SR 2012 Deletion of Rab GAP AS160 modifies glucose uptake and GLUT4 translocation in primary skeletal muscles and adipocytes and impairs glucose homeostasis. American Journal of Physiology: Endocrinology and Metabolism 303 E1273-E1286. (https://doi.org/10.1152/ ajpendo.00316.2012)

Lao XQ, Deng HB, Liu X, Chan TC, Zhang Z, Chang LY, Yeoh EK, Tam T, Wong MCS \& Thomas GN 2019 Increased leisure-time physical activity associated with lower onset of diabetes in 44828 adults with impaired fasting glucose: a population-based prospective cohort study. British Journal of Sports Medicine 53 895-900. (https:// doi.org/10.1136/bjsports-2017-098199)

Larance M, Ramm G, Stockli J, van Dam EM, Winata S, Wasinger V, Simpson F, Graham M, Junutula JR, Guilhaus M, et al. 2005 Characterization of the role of the Rab GTPase-activating protein AS160 in insulin-regulated GLUT4 trafficking. Journal of Biological Chemistry 280 37803-37813. (https://doi.org/10.1074/jbc. M503897200)

Lauritzen HP 2013 Insulin- and contraction-induced glucose transporter 4 traffic in muscle: insights from a novel imaging approach. Exercise and Sport Sciences Reviews 41 77-86.

Madsen SM, Thorup AC, Overgaard K \& Jeppesen PB 2015 High intensity interval training improves glycaemic control and pancreatic beta cell function of type 2 diabetes patients. PLoS ONE 10 e0133286. (https://doi.org/10.1371/journal.pone.0133286)

Mafakheri S, Chadt A \& Al-Hasani H 2018a Regulation of RabGAPs involved in insulin action. Biochemical Society Transactions $\mathbf{4 6}$ 683-690. (https://doi.org/10.1042/BST20170479)

Mafakheri S, Florke RR, Kanngiesser S, Hartwig S, Espelage L, De Wendt C, Schonberger T, Hamker N, Lehr S, Chadt A, et al. 2018 b AKT and AMP-activated protein kinase regulate TBC1D1 through phosphorylation and its interaction with the cytosolic tail of insulinregulated aminopeptidase IRAP. Journal of Biological Chemistry 293 17853-17862. (https://doi.org/10.1074/jbc.RA118.005040)

Maher AC, McFarlan J, Lally J, Snook LA \& Bonen A 2014 TBC1D1 reduces palmitate oxidation by inhibiting beta-HAD activity in skeletal muscle. American Journal of Physiology: Regulatory, Integrative and Comparative Physiology 307 R1115-R1123. (https://doi. org/10.1152/ajpregu.00014.2014)

Maillard F, Rousset S, Pereira B, Traore A, de Pradel Del Amaze P, Boirie Y, Duclos M \& Boisseau N 2016 High-intensity interval training reduces abdominal fat mass in postmenopausal women with type 2 diabetes. Diabetes and Metabolism 42 433-441. (https://doi. org/10.1016/j.diabet.2016.07.031)

Marette A, Richardson JM, Ramlal T, Balon TW, Vranic M, Pessin JE \& Klip A 1992 Abundance, localization, and insulin-induced translocation of glucose transporters in red and white muscle. American Journal of Physiology 263 C443-C452. (https://doi. org/10.1152/ajpcell.1992.263.2.C443)

Marin P, Andersson B, Krotkiewski M \& Bjorntorp P 1994 Muscle fiber composition and capillary density in women and men with NIDDM. Diabetes Care 17 382-386. (https://doi.org/10.2337/diacare.17.5.382)

McBride A \& Hardie DG 2009 AMP-activated protein kinase - a sensor of glycogen as well as AMP and ATP? Acta Physiologica 196 99-113. (https://doi.org/10.1111/j.1748-1716.2009.01975.x)

Meyre D, Farge M, Lecoeur C, Proenca C, Durand E, Allegaert F, Tichet J, Marre M, Balkau B, Weill J, et al. 2008 R125W coding variant in TBC1D1 confers risk for familial obesity and contributes to linkage 
on chromosome 4p14 in the French population. Human Molecular Genetics 17 1798-1802. (https://doi.org/10.1093/hmg/ddn070)

Miinea CP, Sano H, Kane S, Sano E, Fukuda M, Peranen J, Lane WS \& Lienhard GE 2005 AS160, the Akt substrate regulating GLUT4 translocation, has a functional Rab GTPase-activating protein domain. Biochemical Journal 391 87-93. (https://doi.org/10.1042/ BJ20050887)

Miklosz A, Lukaszuk B, Zendzian-Piotrowska M, Kurek K \& Chabowski A 2016 The effects of AS160 modulation on fatty acid transporters expression and lipid profile in L6 myotubes. Cellular Physiology and Biochemistry 38 267-282. (https://doi.org/10.1159/000438628)

Miklosz A, Lukaszuk B, Zendzian-Piotrowska M, Branska-Januszewska J, Ostrowska H \& Chabowski A 2017 Challenging of AS160/TBC1D4 alters intracellular lipid milieu in L6 myotubes incubated with palmitate. Journal of Cellular Physiology 232 2373-2386. (https://doi. org/10.1002/jcp.25632)

Moltke I, Grarup N, Jorgensen ME, Bjerregaard P, Treebak JT, Fumagalli M, Korneliussen TS, Andersen MA, Nielsen TS, Krarup NT, et al. 2014 A common Greenlandic TBC1D4 variant confers muscle insulin resistance and type 2 diabetes. Nature 512 190-193. (https:// doi.org/10.1038/nature13425)

Monzavi R \& Cohen P 2002 IGFs and IGFBPs: role in health and disease. Best Practice and Research: Clinical Endocrinology and Metabolism 16 433-447. (https://doi.org/10.1053/beem.2002.0212)

Morales PE, Bucarey JL \& Espinosa A 2017 Muscle lipid metabolism: role of lipid droplets and perilipins. Journal of Diabetes Research $\mathbf{2 0 1 7}$ 1789395. (https://doi.org/10.1155/2017/1789395)

Morino K, Petersen KF \& Shulman GI 2006 Molecular mechanisms of insulin resistance in humans and their potential links with mitochondrial dysfunction. Diabetes 55 (Supplement 2) S9-S15. (https://doi.org/10.2337/db06-S002)

Nedachi T, Fujita H \& Kanzaki M 2008 Contractile C2C12 myotube model for studying exercise-inducible responses in skeletal muscle. American Journal of Physiology: Endocrinology and Metabolism 295 E1191-E1204. (https://doi.org/10.1152/ajpendo.90280.2008)

Nickerson JG, Alkhateeb H, Benton CR, Lally J, Nickerson J, Han XX, Wilson MH, Jain SS, Snook LA, Glatz JF, et al. 2009 Greater transport efficiencies of the membrane fatty acid transporters FAT/CD36 and FATP4 compared with FABPpm and FATP1 and differential effects on fatty acid esterification and oxidation in rat skeletal muscle. Journal of Biological Chemistry 284 16522-16530. (https://doi.org/10.1074/ jbc.M109.004788)

Nikolic N, Gorgens SW, Thoresen GH, Aas V, Eckel J \& Eckardt K 2017 Electrical pulse stimulation of cultured skeletal muscle cells as a model for in vitro exercise - possibilities and limitations. Acta Physiologica 220 310-331. (https://doi.org/10.1111/apha.12830)

Oberbach A, Bossenz Y, Lehmann S, Niebauer J, Adams V, Paschke R, Schon MR, Bluher M \& Punkt K 2006 Altered fiber distribution and fiber-specific glycolytic and oxidative enzyme activity in skeletal muscle of patients with type 2 diabetes. Diabetes Care 29 895-900. (https://doi.org/10.2337/diacare.29.04.06.dc05-1854)

O'Neill BT, Lauritzen HP, Hirshman MF, Smyth G, Goodyear LJ \& Kahn CR 2015 Differential role of insulin/IGF-1 receptor signaling in muscle growth and glucose homeostasis. Cell Reports 11 1220-1235. (https://doi.org/10.1016/j.celrep.2015.04.037)

Ostman C, Smart NA, Morcos D, Duller A, Ridley W \& Jewiss D 2017 The effect of exercise training on clinical outcomes in patients with the metabolic syndrome: a systematic review and meta-analysis. Cardiovascular Diabetology 16 110. (https://doi.org/10.1186/s12933017-0590-y)

Paglialunga S, Simnett G, Robson H, Hoang M, Pillai R, Arkell AM, Simpson JA, Bonen A, Huising M, Joseph JW, et al. 2017 The RabGTPase activating protein, TBC1D1, is critical for maintaining normal glucose homeostasis and beta-cell mass. Applied Physiology, Nutrition, and Metabolism 42 647-655. (https://doi.org/10.1139/ apnm-2016-0585)
Park SY, Jin W, Woo JR \& Shoelson SE 2011 Crystal structures of human TBC1D1 and TBC1D4 (AS160) RabGTPase-activating protein (RabGAP) domains reveal critical elements for GLUT4 translocation. Journal of Biological Chemistry 286 18130-18138. (https://doi. org/10.1074/jbc.M110.217323)

Park S, Turner KD, Zheng D, Brault JJ, Zou K, Chaves AB, Nielsen TS, Tanner CJ, Treebak JT \& Houmard JA 2019 Electrical pulse stimulation induces differential responses in insulin action in myotubes from severely obese individuals. Journal of Physiology $\mathbf{5 9 7}$ 449-466. (https://doi.org/10.1113/JP276990)

Peck GR, Ye S, Pham V, Fernando RN, Macaulay SL, Chai SY \& Albiston AL 2006 Interaction of the Akt substrate, AS160, with the glucose transporter 4 vesicle marker protein, insulin-regulated aminopeptidase. Molecular Endocrinology 20 2576-2583. (https://doi. org/10.1210/me.2005-0476)

Peck GR, Chavez JA, Roach WG, Budnik BA, Lane WS, Karlsson HK, Zierath JR \& Lienhard GE 2009 Insulin-stimulated phosphorylation of the Rab GTPase-activating protein TBC1D1 regulates GLUT4 translocation. Journal of Biological Chemistry 284 30016-30023. (https://doi.org/10.1074/jbc.M109.035568)

Pehmoller C, Treebak JT, Birk JB, Chen S, Mackintosh C, Hardie DG, Richter EA \& Wojtaszewski JF 2009 Genetic disruption of AMPK signaling abolishes both contraction- and insulin-stimulated TBC1D1 phosphorylation and 14-3-3 binding in mouse skeletal muscle. American Journal of Physiology: Endocrinology and Metabolism 297 E665-E675. (https://doi.org/10.1152/ajpendo.00115.2009)

Pehmoller C, Brandt N, Birk JB, Hoeg LD, Sjoberg KA, Goodyear LJ, Kiens B, Richter EA \& Wojtaszewski JF 2012 Exercise alleviates lipidinduced insulin resistance in human skeletal muscle-signaling interaction at the level of TBC1 domain family member 4 . Diabetes 61 2743-2752. (https://doi.org/10.2337/db11-1572)

Peng YD, Xu HY, Ye F, Lan X, Peng X, Rustempasic A, Yin HD, Zhao XL, Liu YP, Zhu Q, et al. 2015 Effects of sex and age on chicken TBC1D1 gene mRNA expression. Genetics and Molecular Research 14 7704-7714. (https://doi.org/10.4238/2015.July.13.16)

Petersen KF \& Shulman GI 2006 New insights into the pathogenesis of insulin resistance in humans using magnetic resonance spectroscopy. Obesity 14 (Supplement 1) 34S-40S. (https://doi.org/10.1038/ oby.2006.280)

Pfeffer SR 2017 Rab GTPases: master regulators that establish the secretory and endocytic pathways. Molecular Biology of the Cell $\mathbf{2 8}$ 712-715. (https://doi.org/10.1091/mbc.E16-10-0737)

Ragheb R, Shanab GM, Medhat AM, Seoudi DM, Adeli K \& Fantus IG 2009 Free fatty acid-induced muscle insulin resistance and glucose uptake dysfunction: evidence for PKC activation and oxidative stress-activated signaling pathways. Biochemical and Biophysical Research Communications 389 211-216. (https://doi.org/10.1016/j. bbrc.2009.08.106)

Ramm G, Larance M, Guilhaus M \& James DE 2006 A role for 14-3-3 in insulin-stimulated GLUT4 translocation through its interaction with the RabGAP AS160. Journal of Biological Chemistry $28129174-29180$. (https://doi.org/10.1074/jbc.M603274200)

Reed SE, Hodgson LR, Song S, May MT, Kelly EE, McCaffrey MW, Mastick CC, Verkade P \& Tavare JM 2013 A role for Rab14 in the endocytic trafficking of GLUT4 in 3T3-L1 adipocytes. Journal of Cell Science 126 1931-1941. (https://doi.org/10.1242/jcs.104307)

Richter EA \& Hargreaves M 2013 Exercise, GLUT4, and skeletal muscle glucose uptake. Physiological Reviews 93 993-1017. (https://doi. org/10.1152/physrev.00038.2012)

Rinderknecht E \& Humbel RE 1978 The amino acid sequence of human insulin-like growth factor I and its structural homology with proinsulin. Journal of Biological Chemistry 253 2769-2776.

Roach WG, Chavez JA, Miinea CP \& Lienhard GE 2007 Substrate specificity and effect on GLUT4 translocation of the Rab GTPaseactivating protein Tbc1d1. Biochemical Journal 403 353-358. (https:// doi.org/10.1042/BJ20061798) 
Rubin CJ, Zody MC, Eriksson J, Meadows JR, Sherwood E, Webster MT, Jiang L, Ingman M, Sharpe T, Ka S, et al. 2010 Whole-genome resequencing reveals loci under selection during chicken domestication. Nature 464 587-591. (https://doi.org/10.1038/ nature08832)

Russo VC, Gluckman PD, Feldman EL \& Werther GA 2005 The insulinlike growth factor system and its pleiotropic functions in brain. Endocrine Reviews 26 916-943. (https://doi.org/10.1210/er.2004-0024)

Samovski D, Su X, Xu Y, Abumrad NA \& Stahl PD 2012 Insulin and AMPK regulate FA translocase/CD36 plasma membrane recruitment in cardiomyocytes via Rab GAP AS160 and Rab8a Rab GTPase. Journal of Lipid Research 53 709-717. (https://doi.org/10.1194/jlr. M023424)

Sano H, Kane S, Sano E, Miinea CP, Asara JM, Lane WS, Garner CW \& Lienhard GE 2003 Insulin-stimulated phosphorylation of a Rab GTPase-activating protein regulates GLUT4 translocation. Journal of Biological Chemistry 278 14599-14602. (https://doi.org/10.1074/jbc. C300063200)

Schenk S \& Horowitz JF 2007 Acute exercise increases triglyceride synthesis in skeletal muscle and prevents fatty acid-induced insulin resistance. Journal of Clinical Investigation 117 1690-1698. (https:// doi.org/10.1172/JCI30566)

Schiaffino S \& Reggiani C 2011 Fiber types in mammalian skeletal muscles. Physiological Reviews 91 1447-1531. (https://doi. org/10.1152/physrev.00031.2010)

Schweitzer GG, Arias EB \& Cartee GD 2012 Sustained postexercise increases in AS160 Thr642 and Ser588 phosphorylation in skeletal muscle without sustained increases in kinase phosphorylation. Journal of Applied Physiology 113 1852-1861. (https://doi. org/10.1152/japplphysiol.00619.2012)

Smith PJ, Wise LS, Berkowitz R, Wan C \& Rubin CS 1988 Insulin-like growth factor-I is an essential regulator of the differentiation of 3T3L1 adipocytes. Journal of Biological Chemistry $2639402-9408$.

Stenmark H 2009 Rab GTPases as coordinators of vesicle traffic. GT. Nature Reviews: Molecular Cell Biology 10 513-525. (https://doi. org/10.1038/nrm2728)

Stermann T, Menzel F, Weidlich C, Jeruschke K, Weiss J, Altenhofen D, Benninghoff T, Pujol A, Bosch F, Rustenbeck I, et al. 2018 Deletion of the RabGAP TBC1D1 leads to enhanced insulin secretion and fatty acid oxidation in islets From male mice. Endocrinology 159 1748-1761. (https://doi.org/10.1210/en.2018-00087)

Stockli J, Meoli CC, Hoffman NJ, Fazakerley DJ, Pant H, Cleasby ME, Ma X, Kleinert M, Brandon AE, Lopez JA, et al. 2015 The RabGAP TBC1D1 plays a central role in exercise-regulated glucose metabolism in skeletal muscle. Diabetes 64 1914-1922. (https://doi.org/10.2337/ db13-1489)

Stone S, Abkevich V, Russell DL, Riley R, Timms K, Tran T, Trem D, Frank D, Jammulapati S, Neff CDet al. 2006 TBC1D1 is a candidate for a severe obesity gene and evidence for a gene/gene interaction in obesity predisposition. Human Molecular Genetics 15 2709-2720. (https://doi.org/10.1093/hmg/ddl204)

Stuart CA, McCurry MP, Marino A, South MA, Howell ME, Layne AS, Ramsey MW \& Stone MH 2013 Slow-twitch fiber proportion in skeletal muscle correlates with insulin responsiveness. Journal of Clinical Endocrinology and Metabolism 98 2027-2036. (https://doi. org/10.1210/jc.2012-3876)

Szekeres F, Chadt A, Tom RZ, Deshmukh AS, Chibalin AV, Bjornholm M, Al-Hasani H \& Zierath JR 2012 The Rab-GTPase-activating protein TBC1D1 regulates skeletal muscle glucose metabolism. American Journal of Physiology: Endocrinology and Metabolism 303 E524-E533. (https://doi.org/10.1152/ajpendo.00605.2011)

Tanaka T, Nakatani K, Morioka K, Urakawa H, Maruyama N, Kitagawa N, Katsuki A, Araki-Sasaki R, Hori Y, Gabazza ECet al. 2003 Nitric oxide stimulates glucose transport through insulin-independent GLUT4 translocation in 3T3-L1 adipocytes. European Journal of Endocrinology 149 61-67. (https://doi.org/10.1530/eje.0.1490061)
Taylor EB, An D, Kramer HF, Yu H, Fujii NL, Roeckl KS, Bowles N, Hirshman MF, Xie J, Feener EPet al. 2008 Discovery of TBC1D1 as an insulin-, AICAR-, and contraction-stimulated signaling nexus in mouse skeletal muscle. Journal of Biological Chemistry 283 9787-9796. (https://doi.org/10.1074/jbc.M708839200)

Thorens B \& Mueckler M 2010 Glucose transporters in the 21st Century. American Journal of Physiology: Endocrinology and Metabolism 298 E141-E145. (https://doi.org/10.1152/ajpendo.00712.2009)

Treebak JT, Frosig C, Pehmoller C, Chen S, Maarbjerg SJ, Brandt N, MacKintosh C, Zierath JR, Hardie DG, Kiens Bet al. 2009 Potential role of TBC1D4 in enhanced post-exercise insulin action in human skeletal muscle. Diabetologia 52 891-900. (https://doi.org/10.1007/ s00125-009-1294-y)

Treebak JT, Taylor EB, Witczak CA, An D, Toyoda T, Koh HJ, Xie J, Feener EP, Wojtaszewski JF, Hirshman MFet al. 2010 Identification of a novel phosphorylation site on TBC1D4 regulated by AMP-activated protein kinase in skeletal muscle. American Journal of Physiology: Cell Physiology 298 C377-C385. (https://doi.org/10.1152/ ajpcell.00297.2009)

Treebak JT, Pehmoller C, Kristensen JM, Kjøbsted R, Birk JB, Schjerling P, Richter EA, Goodyear LJ \& Wojtaszewski JF 2014 Acute exercise and physiological insulin induce distinct phosphorylation signatures on TBC1D1 and TBC1D4 proteins in human skeletal muscle. Journal of Physiology 592 351-375. (https://doi.org/10.1113/ jphysiol.2013.266338)

Vendelbo MH, Clasen BF, Treebak JT, Moller L, Krusenstjerna-Hafstrom T, Madsen M, Nielsen TS, Stodkilde-Jorgensen H, Pedersen SB, Jorgensen JOet al. 2012 Insulin resistance after a 72-h fast is associated with impaired AS160 phosphorylation and accumulation of lipid and glycogen in human skeletal muscle. American Journal of Physiology: Endocrinology and Metabolism 302 E190-E200. (https://doi. org/10.1152/ajpendo.00207.2011)

Vind BF, Pehmoller C, Treebak JT, Birk JB, Hey-Mogensen M, BeckNielsen H, Zierath JR, Wojtaszewski JF \& Hojlund K 2011 Impaired insulin-induced site-specific phosphorylation of TBC1 domain family, member 4 (TBC1D4) in skeletal muscle of type 2 diabetes patients is restored by endurance exercise-training. Diabetologia 54 157-167. (https://doi.org/10.1007/s00125-010-1924-4)

Wang HY, Ducommun S, Quan C, Xie B, Li M, Wasserman DH, Sakamoto K, Mackintosh C \& Chen S 2013 AS160 deficiency causes whole-body insulin resistance via composite effects in multiple tissues. Biochemical Journal 449 479-489. (https://doi.org/10.1042/ BJ20120702)

Wang Y, Xu HY, Gilbert ER, Peng X, Zhao XL, Liu YP \& Zhu Q 2014 Detection of SNPs in the TBC1D1 gene and their association with carcass traits in chicken. Gene $\mathbf{5 4 7}$ 288-294. (https://doi. org/10.1016/j.gene.2014.06.061)

Wang H, Arias EB, Pataky MW, Goodyear LJ \& Cartee GD 2018 Postexercise improvement in glucose uptake occurs concomitant with greater gamma3-AMPK activation and AS160 phosphorylation in rat skeletal muscle. American Journal of Physiology: Endocrinology and Metabolism 315 E859-E871. (https://doi.org/10.1152/ ajpendo.00020.2018)

Wang H, Arias EB, Oki K, Pataky MW, Almallouhi JA \& Cartee GD 2019 Fiber type-selective exercise effects on AS160 phosphorylation. American Journal of Physiology: Endocrinology and Metabolism 316 E837-E851. (https://doi.org/10.1152/ajpendo.00528.2018)

Whitfield J, Paglialunga S, Smith BK, Miotto PM, Simnett G, Robson HL, Jain SS, Herbst EAF, Desjardins EM, Dyck DJ,et al. 2017 Ablating the protein TBC1D1 impairs contraction-induced sarcolemmal glucose transporter 4 redistribution but not insulin-mediated responses in rats. Journal of Biological Chemistry 292 16653-16664. (https://doi. org/10.1074/jbc.M117.806786)

Williamson DL, Bolster DR, Kimball SR \& Jefferson LS 2006 Time course changes in signaling pathways and protein synthesis in $\mathrm{C} 2 \mathrm{C} 12$ myotubes following AMPK activation by AICAR. American Journal of 
Physiology: Endocrinology and Metabolism 291 E80-E89. (https://doi. org/10.1152/ajpendo.00566.2005)

Xie B, Chen Q, Chen L, Sheng Y, Wang HY \& Chen S 2016 The inactivation of RabGAP function of AS160 promotes lysosomal degradation of GLUT4 and causes postprandial hyperglycemia and hyperinsulinemia. Diabetes 65 3327-3340. (https://doi.org/10.2337/ db16-0416)

Yang ZJ, Fu L, Zhang GW, Yang Y, Chen SY, Wang J \& Lai SJ 2013 Identification and association of SNPs in TBC1D1 gene with growth traits in two rabbit breeds. Asian-Australasian Journal of Animal Sciences 26 1529-1535. (https://doi.org/10.5713/ajas.2013.13278)

Yau SW, Henry BA, Russo VC, McConell GK, Clarke IJ, Werther GA \& Sabin MA 2014 Leptin enhances insulin sensitivity by direct and sympathetic nervous system regulation of muscle IGFBP-2 expression: evidence from nonrodent models. Endocrinology 155 2133-2143. (https://doi.org/10.1210/en.2013-2099)
Zerial M \& McBride H 2001 Rab proteins as membrane organizers. Nature Reviews: Molecular Cell Biology 2 107-117. (https://doi. org/10.1038/35052055)

Zhou QL, Jiang ZY, Holik J, Chawla A, Hagan GN, Leszyk J \& Czech MP 2008 Akt substrate TBC1D1 regulates GLUT1 expression through the mTOR pathway in 3T3-L1 adipocytes. Biochemical Journal 411 647-655. (https://doi.org/10.1042/BJ20071084)

Zhou Z, Menzel F, Benninghoff T, Chadt A, Du C, Holman GD \& Al-Hasani H 2017 Rab28 is a TBC1D1/TBC1D4 substrate involved in GLUT4 trafficking. FEBS Letters 591 88-96. (https://doi. org/10.1002/1873-3468.12509)

Zierath JR, He L, Guma A, Odegoard Wahlstrom E, Klip A \& WallbergHenriksson H 1996 Insulin action on glucose transport and plasma membrane GLUT4 content in skeletal muscle from patients with NIDDM. Diabetologia 39 1180-1189. (https://doi.org/10.1007/ bf02658504)

Received in final form 14 October 2019

Accepted 18 October 2019

Accepted Preprint published online 18 October 2019
(C) 2020 Society for Endocrinology Published by Bioscientifica Ltd. Printed in Great Britain 